\title{
ENTREVISTA COM BERTHOLD ZILLY
}

Por: Claudia Silveyra D’Avila ${ }^{1}$

Traduzida para o espanhol por

Pablo Cardellino Soto ${ }^{2}$

\footnotetext{
${ }^{1}$ Mestranda no Programa de Pós-graduação em Jornalismo da Universidade Federal de Santa Catarina. Florianópolis, Santa Catarina, Brasil. E-mail: sildavia@zedat.fu-berlin.de

${ }^{2}$ Doutor em Estudos da Tradução pela Universidade Federal de Santa Catarina. Bacharel em Letras - Espanhol pela mesma universidade. E-mail: pablocardellino@gmail.com
} 


\section{ENTREVISTA COM BERTHOLD ZILLY}

"Euclides me fez tradutor"

Berthold Zilly, nasceu em 1945 em Danndorf, Norte da Alemanha. É doutor em filologias românicas e germânicas, com tese sobre Molière, pela Freie Universität Berlin, na qual lecionou letras latino-americanas (1974-2010), o que também fez na Universität Bremen (2004-2010). Ministrou cursos intensivos e palestras em universidades latino-americanas, norte-americanas e europeias. Sempre se engajou também na extensão cultural, colaborando intensamente com a difusão da cultura brasileira na Alemanha. Publicou numerosos artigos, resenhas, ensaios sobre literatura brasileira e argentina, com dois enfoques: literatura - história; literatura comparada - tradução. Levou clássicos da América Latina e de Portugal para o alemão, Civilización y barbarie de Domingo $\mathrm{F}$. Sarmiento, Os Sertões de Euclides da Cunha, Memorial de Aires de Machado de Assis, Triste fim de Policarpo Quaresma de Lima Barreto, Confissão de Lúcio de Mário de Sá-Carneiro, Lavoura arcaica de Raduan Nassar. Pratica a tradução como parte integrante do ensino e da pesquisa de línguas e literaturas estrangeiras e dos estudos interculturais. Recebeu diversas condecorações no Brasil e na Alemanha, a mais recente em agosto de 2017, na UERJ, o Prêmio Blaise Cendrars, que é outorgado anualmente pela Associação Brasileira de Literatura Comparada (Abralic), "como reconhecimento a especialista estrangeiro por sua contribuição ao estudo da literatura brasileira em chave comparada". Atualmente, é professor visitante na Pós-graduação em Estudos da Tradução, da Universidade Federal de Santa Catarina. 
Revista da Anpoll (RA): Começando por sua mais recente premiação, como você se sente depois da obtenção do prêmio Blaise Cendrars, concedido pela ABRALIC?

Berthold Zilly (BZ): Bem, em primeiro lugar o que penso e sinto é gratidão pela bela homenagem na Universidade do Estado do Rio de Janeiro, a UERJ, e por ter sido contemplado com esse valioso prêmio, o prêmio Blaise Cendrars. Gratidão também para com a ABRALIC, sua Diretoria, e seu presidente João Cezar pela honra e reconhecimento do meu trabalho em prol da difusão da cultura brasileira, e a Johannes Kretschmer pelas palavras de apresentação em que me inseriu por assim dizer na tradição dos viajantespesquisadores europeus que vieram ao Brasil, desde o século XIX. Estou grato à equipe que colaborou na realização deste magnífico congresso, grato a toda a UERJ, aos professores, funcionários e estudantes que tornaram possível este evento, trabalhando voluntariamente, com muita abnegação, apesar da grave crise e das condições tão adversas pelas quais está passando a Universidade. E me considero honrado também pelo nome do prêmio que remete a um grande poeta, escritor, viajante, mediador cultural suíço-francês, com quem, todas as proporções guardadas, sinto afinidades: a paixão pela cultura e pela gente do Brasil, considerado por ele e por mim uma outra pátria, o desejo de construir pontes entre Brasil e Europa, e também a alta estima pela atividade tradutória. Cendrars sugeriu traduções de literatura brasileira para o francês, e ele mesmo empreendeu algumas, traduziu por exemplo um importante romance sobre a Amazônia, A Selva, de autor português, Ferreira de Castro. Temos em comum também a admiração por Euclides da Cunha, de quem Cendrars quis traduzir a obra-prima: Os Sertões, sem, no entanto, encontrar oportunidade para isso. Aí, eu tive mais sorte, cumprindo de certa forma a intenção do padroeiro do prêmio, embora com outra língua-alvo.

Meu agradecimento se estende ao Brasil e à cultura brasileira que - além da cultura alemã e da francesa - me tem sensibilizado, fascinado, formado humana, estética e intelectualmente, desde há mais de meio século. Sem a literatura brasileira eu não seria o intelectual que sou, também não seria tradutor, não teria os amigos que tenho, seria provavelmente mais cerebral, mas especializado, talvez mais eurocêntrico, talvez menos interessado em ver de modo diferenciado aspectos universais da condição humana. Faço minhas as palavras do historiador francês Fernand Braudel: ${ }^{3}$ "Eu me tornei inteligente indo

\footnotetext{
${ }^{3}$ LIMA, Luís Corrêa. Fernand Braudel (1902-1985). In: Os historiadores: clássicos da história, v. 2: de Tocqueville a Thompson. Petrópolis, Rj: Vozes: PUC-Rio, 2013, pp. 283-284.

Une leçon d'histoire de FERNAND BRAUDEL. Châteairvallon. Journées Fernand Braudel 18, 19 et 20 octobre 1985. Les Editions Arthaud, 1986, Paris. Tous droits réservés. I.S.B.N. 2-70030557-4. Imprimé en France. In : < https://dlscrib.com/queue/une-lecon-d-39 histoire 58c96e91d c0d600a3b339029 docx?queue id=59abda9fdc0d603f3b568ee4>
} 
ao Brasil. O espetáculo que tive diante dos olhos era um tal espetáculo de história, um tal espetáculo de gentileza social que eu compreendi a vida de outra maneira." [Assim reza a citação no livro de Luís Correa Lima; eis aqui o original "Je suis devenu intelligent en allant au Brésil. Le spectacle que j'avais sous les yeux était un tel spectacle d'histoire, un tel spectacle de gentillesse sociale que j'ai compris la vie autrement." ]

Estou muito contente que o prêmio me tenha sido entregue no Congresso da ABRALIC, pois foi um brilhante evento intelectual, cultural e acadêmico de uma importante associação profissional que faz brilhar as letras brasileiras no mundo, justamente aquilo para o que sempre tentei contribuir. E também é um encontro humano, um congraçamento, uma confraternização, palavras só imperfeitamente traduzíveis em alemão. Parece um chavão, mas tem um fundo de verdade, ou seja, a ideia da cordialidade, da afetividade, do caráter pessoal das relações humanas no Brasil, sobre as quais há observações nos relatos de viajantes históricos, nos manifestos modernistas, nos ensaios de Gilberto Freyre, Sérgio Buarque de Holanda, Stefan Zweig, Roberto da Matta, Pedro Monteiro, João Cezar de Castro Rocha e muitos outros. Talvez uma atitude assim nem sempre seja compatível com o imperativo categórico de Kant, mas relações de coleguismo e simpatia, acompanhadas daquele abraço, até agradariam ao filósofo de Königsberg.

\section{Brasil?}

RA: Quer dizer que você tem uma relação não apenas acadêmica com o

BZ: Isso mesmo. Acho a cultura brasileira interessante e simpática, porque, entre outras coisas, ela ainda é bastante visceral, emotiva, principalmente em seus estratos mais populares, além de ser também racional e intelectualizada, naturalmente. Ela vive mais em contato com as bases biológicas e psíquicas do ser humano e da vida social, o corpo, a sensorialidade, a voz, o temperamento, mas também com a espiritualidade, ou seja, é uma cultura antenada com o físico e o metafísico. Na literatura digamos erudita isso se manifesta na importância que tem a cultura popular, a oralidade, o ritmo, a sonoridade, a gestualidade, também o diálogo com outras artes e práticas sociais, com a música, a dança, o teatro, a religiosidade. No seu conhecido ensaio $O$ Narrador, Walter Benjamin enfoca a figura do contador de estórias, valorizando a origem e a dimensão popular, oral, comunicativa da tradição literária, principalmente do conto e da novela. Essa é uma dimensão que no Brasil está mais presente ainda do que na Alemanha, por exemplo, basta ler e ouvir Guimarães Rosa. Benjamin teria gostado muito da literatura brasileira, e da literatura latino-americana de um modo geral. Mas não quero dizer com isso que a cultura brasileira seja predominantemente emotiva, sensorial, lúdica, mágica, mítica, popular-artística, de certa forma pré-moderna, e que a europeia seja sublimada, cerebral, racional, moderna, científica - pensar assim seria outro chavão, o Brasil seria a terra do dionisíaco e a Europa a terra do apolíneo. Não é tão simples, não é por aí. É 
verdade que, tradicionalmente, os europeus tendiam para uma visão um pouco simplificadora: o Brasil forneceria a matéria-prima cultural; a Europa forneceria a análise e a teoria para interpretá-la. Mesmo Cendrars tinha uma pitada desse pensamento, embora fosse amigo dos modernistas e admirasse o crescimento febril, a modernidade e o cosmopolitismo de São Paulo. Por outro lado, o filósofo alemão Max Bense, outro grande amigo e conhecedor do Brasil, interlocutor dos poetas concretos, admirador de Lúcio Costa e de Niemeyer, até percebeu a moderna cultura brasileira como cartesiana, visão certamente unilateral, mas não errada. E há tempo que a Universidade brasileira faz pesquisa de ponta, formando excelentes profissionais, apesar de todos os problemas que a gente conhece, principalmente com os mais recentes cortes de verbas.

RA: Então você acha que qualquer definição da cultura brasileira seria simplificadora e levaria a clichês?

BZ: Sim, embora fosse sempre uma tentação determinar quais as qualidades ou mazelas de uma cultura, e de uma nação. Essas correntes do pensamento sobre o suposto caráter nacional e a psicologia dos povos já tiveram alguma conjuntura, antes da Segunda Guerra Mundial, mas definições e principalmente definições unívocas de uma cultura são arriscadas ou impossíveis, sobretudo em se falando do Brasil, país-continente, e elas podem fomentar um nacionalismo ufanista ou um desprezo do outro ou de si mesmo. Sempre há um leque amplo e múltiplo e até contraditório de características de um país e da sua cultura, há diferenciações e mudanças sociais, regionais, históricas, muito depende também do ponto de vista pessoal e ideológico do observador. Para ver com mais clareza essas questões, muito me valeu o livro de Dante Moreira Leite: "O caráter nacional brasileiro", que justamente desconstrói esse conceito. De qualquer forma, o Brasil é uma grande Kulturnation, uma nação caracterizada culturalmente, num sentido muito amplo, porque aqui a tradicional cultura popular, a cultura de massa, a cultura erudita, elas não estão separadas e compartimentadas, mas vivem transições e misturas produtivas. $\mathrm{Na}$ Alemanha pelo contrário, você tem uma distância bem maior entre a chamada EKultur (cultura erudita, 'séria') e U-Kultur (cultura de entretenimento). Diferentemente da Alemanha, que se deu uma cultura nacional sem ter um Estado nacional, duzentos anos atrás, o Brasil herdou um Estado, tendo que formar em seguida uma cultura nacional, o que vem fazendo até hoje com sucesso, de modo muito produtivo e criativo, graças às suas raízes múltiplas, indígenas, africanas, europeias e à mestiçagem entre elas. E graças ao cultivo de tradições e por outro lado à abertura para inovações novos produtos, técnicas e hábitos, inclusive no âmbito intelectual e artístico. Também abertura para o diálogo com outras culturas. Os brasileiros sempre sabiam [souberam?], mais do que os alemães, que a cultura não é um patrimônio e um acervo fixo, e que é difícil definir uma Leitkultur, como querem políticos conservadores na Alemanha, ou seja um conjunto de valores culturais e comportamentais, a serem 
assumidos pelos imigrantes, algo fixo que você aprende, possui e pronto. Acontece que as culturas sempre estão se diferenciando e misturando, se formando e transformando, e nunca são homogêneas, de modo que as diferenças internas fazem parte delas. Felizmente, hoje em dia, nos Estados democráticos, a total homogeneidade cultural já não é um valor central, seria até um empobrecimento. $\mathrm{O}$ que faz a riqueza e a especificidade do Brasil no plano mundial? Não os commodities, mas a cultura brasileira com sua diversidade e vitalidade, com suas atividades e produções artísticos, costumes, cozinha, esporte, e também com sua produção intelectual e cientifica, por exemplo nos estudos literários e tradutórios, que conheço de primeira mão.

RA: Quando nasceu a relação com a cultura brasileira e o que foi o que mais lhe interessou?

BZ: Tudo começou nos anos sessenta do século XX, e foi desde o começo uma relação múltipla, com a cultura, e com pessoas, com o Cinema Novo, que na altura realmente era novo, com a literatura, especialmente a nordestina. Em 1966, eu estava estudando literatura francesa na universidade de Caen, na Normandia, lá vi Vidas Secas, de Nelson Pereira dos Santos, Deus e o Diabo na Terra do Sol de Glauber Rocha, Os Fuzis de Ruy Guerra, O Cangaceiro, de Lima Barreto, do cineasta desse nome, comecei a ler literatura brasileira, Graciliano sobretudo, em francês ou alemão, comecei a estudar português, e ao mesmo tempo fiz amizade com estudantes brasileiros, sobretudo do Nordeste, e também: cherchez la femme. Portanto, estranho ou não, a região que mais me fascinou foi o Nordeste, e dentro do Nordeste o Sertão, embora eu tivesse lido a partir daí também autores que falam mais da Zona da Mata, das plantações de açúcar, do cacau, das cidades do litoral, Recife por exemplo, José Lins, Amado, Josué de Castro, Jorge de Lima, até conheci pessoalmente dois autores clássicos nordestinos, Gilberto Freyre e José Américo de Almeida, isso foi em 1968, quando vim ao Brasil por primeira vez, com um grupo de estudantes alemães interessados em conhecer problemas do Terceiro Mundo, como se dizia naquela altura. Essa viagem, em plena ditadura militar, me marcou e me empurrou definitivamente para os estudos brasileiros e latino-americanos. Tive o enorme privilégio de estudar um semestre que parece pouco, mas para mim foi decisivo, na USP, em 1969, e lá conheci Antonio Candido com quem fiz dois cursos, dos melhores que fiz na minha vida, também aprendi muito com Aderaldo Castello e Garbuglio. Antonio Candido, em São Paulo, e Peter Szondi, em Berlim, foram os professores que mais me marcaram, embora eu tenha estudado diretamente com eles por muito pouco tempo, infelizmente.

RA: Sua formação é em Letras Românicas, principalmente francesa, como você combinou isso com a sua dedicação à cultura brasileira e sua divulgação? 
BZ: Bom, tive uma formação bastante tradicional, filológica latu sensu, pois na universidade alemã, o termo filologia abrange não só a filologia tradicional, etimologia, história de línguas aparentadas, as românicas por exemplo, edição crítica de textos etc., mas tem um sentido mais amplo. A gente é ou deveria ser filólogo no sentido original do termo em grego: 'amigo da palavra', também 'amigo do logos', estudioso da palavra escrita e falada, da poética, da retórica, da forma linguística do pensamento, de textos configurados esteticamente. E o amigo da palavra sabe que as palavras têm carga emocional, ideológica, política. Usar linguagem é uma maneira de agir, implicando responsabilidade, um compromisso com o logos, a razão, a justiça, o humanismo. Assim, a filologia se aproxima da história e das ciências sociais, também do direito, da filosofia, um pouco de tudo, como a retórica na Antiguidade.

Estudei filologia românica e também a germânica, apesar do meu pendor ao Fernweh, a saudade do longínquo. Mas sempre prezei, embora criticamente, as minhas origens, a cultura alemã. Creio que quem estuda o estrangeiro, o outro, o alheio, faz bem em conhecer e estudar o próprio também, para discernir melhor as qualidades do alheio, e para estabelecer um diálogo intercultural. Este certamente tem uma das suas formas mais intensas, mais sofisticadas e mais duradouras na tradução. Ensinei diversas línguas, alemão, francês, português, espanhol, dentro e fora da universidade, e partes das respectivas literaturas, também como fonte de conhecimentos sobre as respectivas civilizações, usando às vezes a tradução como ferramenta de compreensão e de controle da aprendizagem. Fiz doutorado em literatura francesa, mas fui a maior parte do tempo professor de culturas latino-americanas, com ênfase no Brasil, durante mais de 36 anos na Alemanha, e depois fui convidado para ser professor visitante na Universidade Federal de Santa Catarina, na Ilha de Santa Catarina, onde venho lecionando estudos da tradução e também já dei aulas de literatura alemã. Creio que a minha formação e experiência filológica me foi bastante útil para me entrosar na cultura brasileira. E aproximar-se do Brasil via a França refaz de certa forma um caminho histórico da literatura brasileira, para a qual as letras francesas foram modelares, durante século e meio.

RA: Como professor visitante na área de Estudos da tradução, como encontrou a posição da tradução na universidade brasileira?

BZ: A literatura brasileira me levou para a tradução literária e a universidade brasileira me levou, de uma maneira aprofundada, aos Estudos da Tradução. O traduzir e o refletir sobre o traduzir ocupam espaço importante na universidade brasileira, diferentemente da alemã. A Pós-graduação em Estudos da Tradução, em Florianópolis, por exemplo, congrega uns trinta professores dos diversos ramos das letras, da linguística, da filosofia, da antropologia, do teatro etc. em torno da tradução, sendo, portanto, um programa interdisciplinar, que de forma mais ou menos parecida existe em diversas outras universidades brasileiras. Tradução e pesquisa sobre tradução têm um lugar reconhecido e 
importante na academia, com excelentes teóricos que geralmente também são tradutores, ou seja, tem um bom entrosamento entre prática e pesquisa. Na Alemanha, ao contrário, com pouquíssimas exceções, a tradução e a reflexão tradutológica têm posição marginalizada na academia, embora haja ótimos especialistas, porém bastante isolados e esparsos. $\mathrm{O}$ traduzir nem é considerado produção acadêmica, é considerado atividade mais bem técnica, ou então artística, conforme o tipo de texto, de qualquer forma isso que não dá créditos para a carreira de um professor, a não ser, na filologia clássica, quando você traduz e comenta um autor grego por exemplo. O relativo desprestigio da tradução na universidade alemã poderia surpreender, pois há séculos, a tradução e a reflexão sobre ela, muitas vezes combinado com o pensamento hermenêutico na filosofia, na teologia, nas letras, no direito, ocupa e preocupa as melhores inteligências alemãs, basta pensar em Luther, Schleiermacher, Wieland, Lessing, Goethe, Hölderlin, os irmãos Schlegel, Tieck, Benjamin, Gadamer e muitos outros, até hoje todos eles sendo estudados, também no Brasil. Na universidade brasileira a tradução e os estudos da tradução são bem institucionalizados, e têm um alto nível, de modo que alguém como eu aqui tem excelentes interlocutores e excelentes condições de trabalho.

RA: Berlim é um importante ponto de encontro para pessoas que se interessam pela América Latina e para os próprios latino-americanos. Isso lhe ajudou a cultivar o seu apego ao Brasil?

BZ: Sim, sem dúvida, nesse sentido Berlim também me formou, e me deu oportunidade de ser algo como um agente cultural. Esse é um aspecto pouco documentado das minhas atividades, e como não tem currículo Lattes na Alemanha, eu mesmo não registrei isso. Mas que foi muito enriquecedor para mim pessoal e profissionalmente, e para algumas outras pessoas também, espero. Pois desde 1969, depois de eu voltar de uma estadia de um ano no Brasil, sempre organizei ou ajudei a organizar algo, ou fui convidado, como moderador, tradutor, participante, de alguma maneira, centenas de eventos culturais e acadêmicos em torno da cultura brasileira: leituras, palestras, apresentações musicais, peças de teatro, mesas redondas, exposições, projeções de filmes. Gosto de organizar encontros e cooperar com pessoas nisso. Recebi artistas, jornalistas, professores brasileiros na Alemanha, estou me lembrando p.e. que fui intérprete numa entrevista coletiva de Eduardo Coutinho no Festival de cinema de Berlim, quando estava estreando Cabra Marcado para morrer, encontrei inúmeros intelectuais etc. em Berlim, Paulo Singer, Miriam Goldenberg, Tereza Raquel, João Antônio, Loyola Brandão, Ubaldo Ribeiro, Bernardo Carvalho, Antonio Callado, Rafael Cardoso, Roberto da Matta, Rubem Fonseca, Evando Nascimento, o casal Freitag-Rouanet, Antônio Torres, Silviano Santiago, Ligia Fagundes Telles, Isabel Lustosa, Raquel de Queiroz, Zé Celso, Roberto Schwarz, Arnoni Prado, Roberto Ventura, Darcy Ribeiro, Karim Ainouz, Susana Amaral, Fernanda Montenegro, Haroldo de Campos, João Luiz Lafetá, João Klug, João 
Cezar, são nomes que estão me ocorrendo agora, poderia citar uma centena de outros. Foram eventos em universidades, na Embaixada Brasileira, em feiras do livro, em livrarias, casas de cultura, também em outras cidades alemãs e europeias. De 1995 até 2005 existiu em Berlim, por iniciativa de Sergio P. Rouanet, o ICBRA, Instituto de Cultura Brasileira na Alemanha, no qual fui bastante ativo. A presença cultural do Brasil no exterior, como qualquer trabalho de extensão cultural, vive - também - através de inúmeros pequenos eventos, e para eles o entusiasmo de ativistas culturais é fundamental. Felizmente o Brasil tem na Alemanha, e na Europa de um modo geral, muitos amigos, que com prazer ajudam a divulgar cultura brasileira.

RA: Nem todos são nomes de literatos ou críticos literários. A interdisciplinaridade fez parte de sua formação e de seu trabalho intelectual?

BZ: Sim, claro, trabalhei num instituto interdisciplinar, o LateinamerikaInstitut da Freie Universität Berlin, a FU, onde se leciona e pesquisa economia, ciência política, antropologia, sociologia, história, literatura, tudo com o denominador comum da América Latina. Sempre tive contato com colegas e estudantes de outras áreas, às vezes até com estudantes da medicina, teologia, direito, história da arte. Também dava aulas de língua portuguesa e de civilização brasileira para estudantes de economia, sociologia, antropologia, lendo textos dessas áreas com eles. Conversava com colegas da sociologia ou história ou outras áreas sobre os mais diversos temas não-literários, o que me facilitava contextualizar a literatura. Não perdi o contato com os estudos germanísticos, por exemplo como membro de bancas de doutorado de estudantes brasileiros, com teses sobre literatura alemã. Também fiquei marcado pelo movimento estudantil dos anos 60 e 70, quando era quase obrigatório você ler Marx, Freud, Lukács, Benjamin, Wilhelm Reich, Max Weber, a Escola de Frankfurt, especialmente Adorno, também Marcuse, a Teoria da Dependência, esta um aporte importante da América Latina para pensar as origens e causas da pobreza e das desigualdades no mundo. Tudo isso é muito bom para um crítico literário, pois a literatura, principalmente a partir do Naturalismo do final do século XIX, pode falar de todos os setores da realidade, todos os temas, dialogando com todas as atividades artísticas, cientificas e práticas. $\mathrm{O}$ crítico literário e o tradutor precisam ser intelectuais abertos, polivalentes, enciclopédicos, dispostos para entrosar-se em quase todos os campos do saber humano, esse seria o ideal, de qualquer forma. No Brasil, na América Latina, sempre teve grande importância o ensaio, gênero que pertence à literatura, mas também ao pensamento social e histórico, eventualmente até ao pensamento científico, à crítica literária e cultural. Veja também a crônica, na qual o Brasil é quase campeão mundial, e que oscila entre jornalismo e literatura.

Bem, tudo isso me deu um contato intenso, concreto, íntimo com diversos aspectos da realidade brasileira, o que é bastante útil para quem faz tradução. Como tradutor, me deparo também com o problema de que qualquer texto tem 
uma espécie de subtexto, conhecimentos e atitudes que o autor pressupõe nos leitores, pressuposições de todos os tipos, intertextuais e extratextuais, sem as quais é difícil entender o texto. Quando Machado de Assis, ou melhor, o seu narrador, Conselheiro Aires, fala do 13 de maio, do Cemitério São João Batista, da Rua do Ouvidor, da Guerra do Paraguai, do Morro do Castelo, do espiritismo, da questão militar, de Camões, o tradutor tem a tarefa primeiro de pesquisar para entender esses subtextos, e de fornecer ao leitor estrangeiro os necessários conhecimentos intertextuais e extratextuais, através de paratextos contextualizadores sobre temas literários, geográficos, históricos, sociológicos, e assim por diante, dependendo das áreas tematizadas da realidade.

De um modo geral, creio que são essas as duas vertentes principais do meu perfil intelectual e do meu trabalho, da minha abordagem da literatura: a vertente filológica, literária, estética, comparatista, por um lado, e a histórica, sociológica, política por outro lado. Creio que as duas se complementam, pois o texto é um fato estético, a ser contemplado em sua autonomia, mas também um fato social, a ser contemplado como expressão, interpretação da realidade extraliterária e até como um elemento constitutivo dela.

RA: Voltando ao aspecto afetivo do seu trabalho, que envolve também a relação entre objetividade e subjetividade do pesquisador com respeito ao objeto estudado. Ajuda ou prejudica amar o objeto de estudos?

BZ: Boa pergunta e ela vai muito além dos estudos literários ou da tradução. Pois me parece difícil a gente se dedicar anos a fio a uma atividade que nos seja indiferente, ou até desagradável. Infelizmente isso acontece com muitos trabalhadores no mundo inteiro, nas fábricas, no comércio, na agricultura, ou seja, muitos fazem um trabalho alienado, trabalho visto só como um mal necessário. O cientista, o intelectual, o professor, geralmente têm mais possibilidade de gostar do trabalho que fazem, de se identificar com ele. Mas precisam de um forte interesse cognitivo, uma curiosidade, um certo carinho pela disciplina em que trabalham e também pelos assuntos que pesquisam e ensinam. Esse interesse deve ser por um lado objetivo, isento de paixões, sine ira et studio, como diziam os romanos, com certa distância, para poder enxergar criticamente todos os aspectos de uma questão, de um tema, de um objeto, de um indivíduo ou de um grupo. Mas é bom também, por outro lado, que a gente, como intelectual e acadêmico, tenha uma motivação emocional, que pode ser simpatia, ou até empatia, isso é bom para uma abordagem hermenêutica, tentando rastrear e refazer o processo de produção e gênese de uma obra, de um acontecimento, de uma corrente histórica ou cultural, dentro do seu contexto social e mental. Excepcionalmente, até uma antipatia contra o objeto de estudos, contra uma ditadura, contra guerras, contra uma retórica mentirosa pode ajudar também o processo cognitivo, de qualquer forma uma emoção que nos dê energia mental para um longo trabalho de pesquisa que exige paciência e esforço. Sem uma certa relação afetiva e moral por exemplo com um texto, seus personagens, ou 
elementos da trama, o estilo, é difícil mergulhar numa obra e conviver com ela, ver como ela funciona, como exerce o seu impacto, qual o seu potencial de significados em outra cultura. Tive a grande sorte de fazer da minha paixão a minha profissão, algo de que gosto de fazer desde menino: ler, falar, discutir sobre línguas e literaturas, e ideias nelas expressas. Acho que o que não me falta é curiosidade, prazer, talvez até paixão pela literatura em geral, e especialmente pela literatura brasileira em seu diálogo com outras literaturas.

Agora, a questão da subjetividade e objetividade, isso é "ein weites Feld", um campo vasto e inesgotável, para citar uma expressão de Theodor Fontane e Günter Grass. Nas ciências humanas, total objetividade é impossível, mas a gente pode e deve aspirar à verificabilidade ou pelo menos à plausibilidade intersubjetiva das nossas pesquisas, reflexões e interpretações, para que os nossos interlocutores ou leitores possam entender, respeitar e talvez até aceitar e melhorar o nosso raciocínio. Pois a verdade em última análise se cristaliza em um processo coletivo, de diálogo, controvérsia e cooperação.

Falando da minha subjetividade, sempre fiquei fascinado com figuras como o personagem principal de Triste fim de Policarpo Quaresma de Lima Barreto, que traduzi para o alemão. Ele é um Dom Quixote do patriotismo social que vive estudando o Brasil, mas só através de livros, durante trinta anos em todos os seus aspectos, regiões, épocas, riquezas naturais e culturais, para poder sugerir reformas no sentido de melhorar a vida dos brasileiros, primeiro na área cultural, depois na agricultura, e finalmente na política. Atitude louvável, mas que no caso concreto oscila entre generosa e ridícula, devido à falta de conhecimento empírico da realidade, falta de viagens, falta de espírito crítico. E há uma elite que sabota qualquer reforma iniciada para o bem da população.

RA: Parece que você como estudioso do Brasil se identifica bastante com personagens que fazem isso mesmo, pesquisar o Brasil.

BZ: Bem, identificar, não sei, mas claro que fico admirado ou sensibilizado, ou outras vezes indignado com situações ou com personagens, penso nelas, e penso em situações parecidas de que tenho conhecimento, ou em que eu mesmo estive ou poderia estar um dia. Claro que a gente tem uma relação também emocional ou sentimental não só com textos, mas também com alguns personagens, me senti próximo de Euclides pesquisando a verdade sobre a guerra de Canudos, e creio que a gente até pode se impressionar com personagens distantes da gente, como Paulo Honório, em São Bernardo, o caboclo que chega a ser fazendeiro rico mas que destrói a sua própria felicidade, por sua ganância, desconfiança, brutalidade. Pode haver algo como empatia sem identificação, acho. Mas é verdade, me sinto próximo do tipo do pesquisador patriótico, abnegado, que procura conhecer a fundo o seu país, para ajudá-lo a ser mais justo, desenvolvido, civilizado. Há, na realidade e na ficção, esses pensadores que pesquisam o Brasil para torná-lo melhor, são patriotas íntegros, cultos e idealistas, não xenófobos, como foram Alexandre Rodrigues Ferreira, embora 
este fosse português, Gonçalves Dias, Taunay, Couto de Magalhaes, Euclides, Candido Rondon, Carlos Chagas, Mário de Andrade, Antonio Callado, Darcy Ribeiro e muitos outros. $E$ às vezes viajantes estrangeiros, também desempenham esse papel, como Langsdorff, Martius, Hercule Florence, Rugendas, Ferdinand Denis e muitos outros. Pessoas que querem, sem muita ambição egocêntrica, pôr em prática os seus conhecimentos e valores humanistas, querendo ser úteis também em termos práticos. Como Policarpo Quaresma, que deseja trabalhar "para a grandeza e a emancipação da Pátria". Depois ele questiona o patriotismo oficial, com razão. Emancipação, aqui significa, também, libertação e inclusão das camadas subalternas, cidadania e dignidade para todos, isso me toca, sim. Que adiantam conhecimentos e teorias se não melhoram o mundo? A decisão de Policarpo de aplicar o seu saber na prática até lembra um famoso aforismo de Karl Marx, a $11^{\mathrm{a}}$ tese sobre Feuerbach: „Die Philosophen haben die Welt nur verschieden interpretiert, es kömmt darauf an, sie zu verändern": "Os filósofos têm apenas interpretado o mundo de modos diferentes; o que importa é transformá-lo." Você me permite uma observação sobre a tradução deste ditado? Esta que improvisei, como todas as que conheço, têm um problema, não semântico, mas estilístico, bom exemplo da importância da forma, da sintaxe, do ritmo, e da reflexão tradutória, até em textos não literários. Pois a frase em alemão é um paralelismo de duas orações que ambas terminam com um verbo, opondo estruturalmente o "interpretar" e o "transformar". Como em português é difícil você colocar o verbo depois do objeto direto - só Guimaraes Rosa faz isso de vez em quando - a tradução não consegue reconfigurar essa estrutura. Assim às vezes a gente esbarra em limites da traduzibilidade, principalmente nos planos sintático e sonoro. Aliás, Marx era um mestre da língua alemã.

RA: Você acha que o Brasil tem uma atração especial para estrangeiros? Por quê?

BZ: O Brasil exerce atração muito especial, há séculos, não sei por quê, desde os tempos do descobrimento ele encantou muitos estrangeiros: Pero Vaz de Caminha, Vespucci, Staden, Jean de Léry, Maurício de Nassau e sua equipe, o pintor Eckhout por exemplo, depois os integrantes das missões estrangeiras na época de Dom João VI e sua nora Dona Leopoldina, Taunay, Wied, Florence, também mais tarde legiões de naturalistas, pintores e etnólogos, como KochGrünberg, que registrou as lendas em torno da figura de Macunaíma, fonte de inspiração para Mário de Andrade. Esse fascínio tem a ver com as muitas descobertas científicas e antropológicas que se podia fazer aqui, pois o Brasil era uma imensa terra incógnita, mas não só. Até gente que nunca esteve no Brasil, como Montaigne, Humboldt, Goethe, Döblin ficaram fascinados com este país, escreveram sobre ele. Goethe lamentou, que, ao conhecer o Brasil através de leituras e também conversas com Eschwege e Martius, já tivesse mais de sessenta anos, sem condições de viajar pessoalmente para cá. Faz uns dez anos, 
um historiador alemão, Sylk Schneider, compilou e comentou tudo o que Goethe escreveu e falou sobre o Brasil - isso deu um livro de 200 páginas! Por que tantos alemães consideram o Brasil um Sehnsuchtsland, país da saudade? Talvez um pouco pela extensão quase infinita, riqueza e beleza do território, pela diversidade espantosa das paisagens, das populações, das expressões culturais, a hospitalidade da população, o enorme potencial de desenvolvimento do país, que assim se presta a servir como tela de projeções, como terra prometida, visões edênicas, sobre as quais Sérgio Buarque de Holanda escreveu importante livro com enfoque na época dos descobrimentos, mas são visões que sobreviveram, não só em Stefan Zweig. Se misturam com visões pessimistas ou até terrificantes e infernais, e na literatura mais moderna estas últimas até parecem prevalecer, com muita crítica social, muito retrato da violência, injustiça social e jurídica, da corrupção; mas a esperança morre por último, e realmente, para quem não vive na miséria, o Brasil pode ser uma terra muito atraente. Não conheço estrangeiro que depois de algum contato mais aprofundado com o Brasil não se tivesse apegado a este país. Todos parecem seguir o lema: "einmal Brasilien - immer Brasilien", uma vez Brasil - Brasil para sempre.

\section{RA: E por que o seu fascínio com o sertão?}

BZ: Como eu já disse, sempre me senti bastante atraído pelo sertão, a sua paisagem, sua história, o seu imaginário, a sua música, Luís Gonzaga, os movimentos sócio-religiosos, os cangaceiros, e suas contradições sociais, as ligas camponesas, pode ser que haja aí algum romantismo e exotismo, um certo gosto por uma realidade diferente, até oposta ao mundo vivido e à civilização urbana que a gente conhece, um certo aventureirismo mental. Mais tarde, nos anos setenta, quando passei dois anos como professor visitante em Fortaleza, li $O s$ Sertões, ou tentei ler, impressionando-me com seus painéis grandiosos, as cenas dramáticas e trágicas da guerra, o martírio do homem e da natureza, os aspectos infernais e heroicos dos dois, a injustiça e a luta pela justiça, aprendi o que é religiosidade popular, coronelismo, a seca como fenômeno não só físico mas também antropógeno, e o problema do colonialismo interno, quando o governo trata o sertão como se fosse um território estrangeiro, ocupado pelo Brasil, fenômeno que mais tarde também conheci na Argentina.

Os Sertões, discutindo a história e os problemas de uma região carente, discute problemas da nação, e até da humanidade. Não é por acaso que este ensaio poético-científico-histórico, como outras obras, livros, peças de teatro ou filmes, que nasceram da observação e da reflexão sobre o interior pobre, seco e atrasado, são considerados importantes interpretações de seus países, transcendendo o regional e o estritamente literário e artístico, e constituindo "lugares de memória", no sentido de Pierre Nora, não só Os Sertões, mas também Facundo de Sarmiento, Radiografía de la pampa de Martínez Estrada, El Llano en llamas de Rulfo, Los de abajo de Azuela, sendo até obras fundacionais, no sentido de Doris Sommer. Têm como palco da trama, como 
objeto de reflexões, e quase como protagonista regiões pouco desenvolvidas, violentas, "bárbaras", , maltratadas pelas elites, e talvez por isso irrequietas e às vezes revoltosas. Ali o Estado moderno está ausente ou muito reduzido, são regiões de "estatalidade limitada", limited statehood, como dizem os cientistas políticos, como se pertencessem a um Estado falido, failed state. Territórios que volta e meia chamam a atenção, quando a permanente violência se transforma em guerra civil, e quando acontece uma emigração em massa, como ainda hoje acontece em muitas partes do mundo. Quem manda lá não são o Estado, o município, a sociedade civil, mas os coronéis, caciques, caudillos, precursores dos warlords em países da África e da Ásia de hoje, aliados ou inimigos do governo central ou da oposição, quando esta existe. Isto você tinha no pampa, nos lhanos, nos sertões, nas selvas, no altiplano até há poucas décadas atrás, e as literaturas latino-americanas falam disso. $\mathrm{E}$ isso ainda existe em espaços suburbanos, nas favelas, verdadeiras no-go-areas, mini-estados dentro do Estado, onde as autoridades constituídas quase não têm autoridade, como antigamente no sertão, basta ler Cidade de Deus, de Paulo Lins.

São regiões e sociedades menos complexas, em que porém se colocam questões existenciais, em formas especificas e datadas, mas que nas estruturas profundas são universais. Assim funcionam, para o observador, e para ao leitor, como laboratórios sociológicos e psicológicos da condição humana: como se pode organizar a satisfação das necessidades básicas, em nível individual, municipal, nacional? Como prover comida, moradia, saúde, educação, o metabolismo com a natureza, que é inimiga e amiga ao mesmo tempo, como construir a convivência civilizada, no plano privado e político, organizar o trabalho, a administração, a política, como lidar com poder e abuso de poder, justiça e injustiça, cooperação e exploração, anelo de liberdade, cidadania, guerra e paz, também: como encarar a luta entre o bem e o mal, dialeticamente entrelaçados, e tão difíceis, às vezes, de serem definidos?

Essas paisagens do interior, física e economicamente carentes, podem ser ricas cultural e metafisicamente. Não deve ser por acaso que algumas religiões do mundo, o judaísmo, o cristianismo, o islamismo, tenham nascido em regiões marginalizadas, pobres, secas, quase desérticas, do Oriente Próximo, regiões associadas por muitos autores latino-americanos ao sertão, ao pampa e ao llano. $\mathrm{O}$ sertão incentiva o viajante à meditação, por ser pouco habitado, pouco confortável, com horizonte amplo e bonito, céu majestoso e sugestivo, às vezes com nuvens enormes, mas pouca chuva, com matizes cambiantes de luz conforme as horas do dia e da estação do ano. Também um povo acolhedor, lhano, perseverante, sabendo contar muitas histórias, reais e fantásticas, um povo que não se resigna, que luta, que dá uma volta por cima. Espero que eu não esteja idealizando demais o meu querido sertão.

RA: Por que, mais especificamente, Os Sertões lhe fascinou tanto? 
BZ: Canudos foi uma das poucas ocasiões em que o povão explorado ou abandonado, e sempre desprezado pelas elites, pelos poderes constituídos, pelos letrados, jornais, igreja, pelo mundo todo, esse povo tomou seu destino nas suas próprias mãos, deixando de ser apenas objeto, virando por um brevíssimo período sujeito da sua história. Fico comovido em ver a empatia e o entusiasmo de Euclides, ver como ele supera, parcialmente pelo menos, os seus próprios preconceitos racistas e antipopulares, como retrata e admira os esquecidos da história e das letras que se reúnem e se organizam para fundar uma comunidade, quase uma cidade, num semideserto. Essa comunidade não é exatamente democrática, mas muito mais igualitária e muito mais baseada no consenso e na participação de todos do que a situação dos vaqueiros e lavradores nas fazendas e nas cidades, dominadas pelas estruturas coronelísticas. Isso explicou o grande afluxo de sertanejos para lá, o que irritava os latifundiários da região. E essa "Tróia de taipa", sem ajuda de fora, sem ajuda de ninguém, é capaz de satisfazer as necessidades básicas de dez ou quinze mil pessoas. Condenando a destruição dessa comunidade Euclides também se acusa a si mesmo pois ele mesmo participou nessa campanha de extermínio, ainda que não como combatente direto. Tem toda razão quando chama isso de tragédia, pois os dois partidos, pelo menos subjetivamente, defendiam nobres princípios e propósitos, uma vida conforme a fé de Deus versus a Nação, a República e a Civilização - condição, segundo Hegel, para uma colisão trágica. Porém, a Civilização lá se voltou contra si mesma virando bárbara, inclusive por não dialogar com os supostos bárbaros. Ela quis impor o progresso autoritariamente, como fez na campanha contra a varíola que provocou a Revolta da Vacina no Rio de Janeiro em 1904. Com o seu livro, Euclides problematiza também o papel do intelectual diante das injustiças sociais e das reivindicações dos injustiçados, que ele, por outro lado, não idealiza. E Euclides teve um insight que vários grandes escritores e pensadores também tiveram, como Rousseau, Diderot, Goethe no seu Fausto, e que Horkheimer e Adorno formularam filosoficamente como a Dialética do Esclarecimento. Que é também a dialética da Civilização, da Modernidade, até da democracia que promete progresso tecnológico, administrativo e cientifico, maior domínio da natureza, a substituição do mito pelo saber, maior bem-estar, menos sofrimento, mas que no plano da realidade social e ética produz às vezes o contrário, promove guerras, desigualdade social, trabalho escravo, marginalização ou destruição de populações tradicionais sem lhes oferecer condições alternativas de sobrevivência digna, criando novos mitos, autoritarismos e até fanatismos. É isso o que Euclides quer dizer, entre outras coisas, quando chama a rua do Ouvidor um "atalho das trilhas do sertão".

RA: Foram essas temáticas, esses conflitos, essas paisagens que inspiraram você a traduzir Os Sertões?

BZ: Sim, quis entender Os Sertões, tive problemas, procurei tradução, não achei, aí resolvi eu mesmo fazê-la, e assim virei tradutor, de certa forma: 
Euclides me fez tradutor. Considero o traduzir como crítica literária aplicada, ou até, como dizem os alemães que fazem de tudo uma ciência: ciência da literatura aplicada, ou seja, tradução como continuação dos estudos filológicos-literários com outros meios. No fundo, não sou tradutor profissional, quando muito sou tradutor bissexto. Mas já estava perto de ser tradutor, pois o trabalho do crítico literário em grande parte é igual ao do tradutor: dissecar o texto, pesquisar a sua estrutura, os elementos e a relação entre eles, entender como essa estrutura funciona, como vive, no diálogo com o leitor, e no contexto histórico-social, dentro da vida literária de um modo geral. Ou seja, existe a fase mais bem analítica e a fase mais bem interpretativa da tarefa do crítico, que pode entrar, mais ou menos profundamente, nas esferas da psicologia, antropologia, sociologia.

Todo tradutor, portanto, também é crítico, pelo menos crítico implícito, mas ele vai além, ele não só estuda a anatomia do texto, a sua fisiologia, a sua vida no contexto cultural, social, político, o que também faz o bom crítico, principalmente aquele que faz um close reading ou uma explication de texte. Mas o tradutor além disso aproveita a análise, a identificação das principais propriedades e significados do texto-fonte para produzir um novo texto literário, em outra língua, em que estejam preservadas em forma metamorfoseada essas propriedades, a sintaxe, o vocabulário, o ritmo, as metáforas, figuras sonoras, as alusões intertextuais, o efeito intelectual e emocional no leitor, na medida do possível. O tradutor insufla outra vida ao texto, o faz reviver em outras latitudes, em outra cultura, outra época talvez. O ideal seria que a tradução produzisse efeitos semelhantes no novo leitorado, ideias, imagens, emoções parecidas com aquelas que tem o leitor do original, mas em diálogo com a cultura de chegada. Tentei fazer isso com Os Sertões, um ensaio polivalente que tem algo de um romance, de um drama, de um poema, de um 'gênesis' do Brasil, de um panfleto político, de um discurso fúnebre. Queria resgatar não só o aspecto científico do texto, os termos geológicos, botânicos, filosóficos, usados às vezes metaforicamente, mas também a qualidade retórica do livro, que imagino como manuscrito de um grande discurso que Euclides, em um amplo anfiteatro, dirige à nação brasileira, aos seus governantes e letrados, para informá-los, repreendêlos, exortá-los em favor do sertão e dos sertanejos, em favor de um Brasil mais justo e mais pacífico. Tentei recriar o ritmo e o elã dessa oralidade erudita, cheia de alusões mitológicas, bíblicas, positivistas, mas também de sabedorias dos próprios caboclos. Acredito no ideal de uma estética da exatidão, na análise e na recriação, sabendo que um ideal a rigor não alcançável, mas a gente tenta.

RA: Você acha que a literatura brasileira tem maior compromisso com a realidade do que a europeia?

BZ: Nas aulas e nos tratados de teoria literária se ensina que, na literatura, o que importa não é o quê, mas o como. É verdade, a literatura é a arte da palavra, a arte de configurar palavras e suas conexões, ao nível da colocação, do 
sintagma, da frase, do período, do parágrafo, do capítulo, e do texto todo. Estudamos textos em sua configuração linguística, estética, temática, emocional e assim por diante. E como tradutor, tenho que me concentrar primeiro na linguagem e sua organização, ao passo que a composição da trama e dos caracteres só o preocupa na medida em que ela sempre aparece configurada linguisticamente. À primeira vista, só temos a superfície linguística, o resto é trabalho do leitor, interpretação. O que difere a linguagem literária da linguagem cotidiana ou técnica, também da linguagem cientifica, é justamente a forma, a feitura estética, a função poética como diz Jakobson, a preponderância desta com respeito às outras funções de um texto, a referencial, a expressiva e a apelativa, sobretudo. Mas isso não quer dizer que o quê não importe. Imaginemos $O s$ Sertões de Euclides da Cunha tal qual conhecemos esse texto, mas com uma diferença, uma hipótese: seria pura ficção, nunca teria acontecido guerra de Canudos, seria tudo puro romance, referindo-se talvez vagamente a guerras religiosas e guerras civis em alguma parte do mundo, mas não haveria lugar com nome ou características de Canudos nem guerra no sertão da Bahia. Como leríamos o livro? Nenhuma palavra ficaria mudada, mas Antônio Conselheiro, o general Arthur Oscar, Pajeú, a Igreja Nova, o rio Vaza-Barris, a degola dos prisioneiros só existiriam como entidades fictícias, não como passado real, extraliterário. Com certeza leríamos o livro de outra maneira, com menos emoção, com menos lucro intelectual, pensaríamos menos: tua res agitur, que se trataria de assunto teu, meu, nosso, aprenderíamos menos sobre o Brasil, sobre o sertão, sobre "as loucuras e os crimes das nacionalidades", como diz Euclides no final. Se esse livro não me ajudasse a compreender melhor a realidade eu não o teria traduzido.

A relação do texto com o mundo real é fundamental para a recepção e a interpretação de uma obra. Ainda que saibamos que a realidade extra-textual, principalmente em se tratando de épocas remotas, não é acessível diretamente, mas através da memória das pessoas e coletividades, através de textos escritos, imagens, objetos, e nunca pode ser reconstruída em sua integridade. Mas isto não invalida a importância do fato, por mais difícil que seja defini-lo em sua totalidade, de modo que uma boa dose de positivismo, embora apimentada de dúvidas epistemológicas e construtivistas, é útil e necessária. Euclides dizia de si mesmo que, para escrever, era como certos pássaros: para alçar voo precisava de um galho, e este galho era o fato.

Por outro lado: por que ele não escreveu um relato puramente factual e objetivo, puramente jornalístico ou científico, militar, técnico, antropológico etc.? Pois ele sabia que só relatar fatos não faz jus aos fatos nem aos leitores. Precisava da imaginação para dar vida ao relato dos fatos, inseri-los na trama de uma narrativa, aquilo que o historiador norte-americano Hayden White chama de emplotment, para encenar os acontecimentos em painéis e cenas imponentes e impactantes. Para isso, precisava conhecer a mentalidade dos personagens relatados, a poesia e a religiosidade do povo, fazer uma espécie de antropologia 
poética, não apenas para tornar o relato mais acessível ao público leitor, mas para entender melhor a realidade acontecida, sua estrutura, seu desdobramento, os seus imaginários coletivos, os seus lados subjetivos. Queria entender a guerra em sua totalidade, entender os sertanejos e os soldados, entender a civilização assassina, tinha por assim dizer uma quase fanática vontade hermenêutica. Esta não iria longe sem o "consórcio da ciência e da arte", como Euclides chamou a sua poetização da história e da ciência.

Para Hegel, a arte não só permite, mas ela deve revelar a verdade, e isso de uma maneira plástica, como "das sinnliche Erscheinen der Idee", a "aparição sensorial da ideia", mais ou menos assim. Se Euclides quis nos comover em favor do povo menosprezado do interior, através de um retrato de guerra, das suas causas, condições, características, consequências, se ele chamava $O s$ Sertões um "livro vingador", isso seria um abuso da literatura? Apelar para a solidariedade com os vencidos e injustiçados não seria uma das funções genuínas da literatura? E creio que não é só Euclides quem viu essa responsabilidade das artes pela construção de um imaginário verdadeiro e ao mesmo tempo crítico e utópico, com relação às realidades nas Américas e no mundo. Esse compromisso existe desde a Independência, desde José Bonifácio, Macedo, Manuel Antônio de Almeida, Castro Alves, Machado, Pompeia, Graciliano e centenas de outros autores. Inclusive porque, até ao século $\mathrm{XX}$, havia pouca divisão de trabalho intelectual no Novo Mundo, de modo que os artistas e literatos se achavam na necessidade de assumir funções de geógrafos, antropólogos, historiadores, psicólogos e assim por diante. Os poetas e escritores foram pioneiros na descrição do dia a dia do povo, do seu mundo-vivido, da sua mentalidade, dos costumes e relações sociais, nas cidades, no sertão, na selva.

RA: Atualmente, você está trabalhando numa nova tradução de Grande Sertão: Veredas para o alemão. Quais os desafios, também em comparação com Os Sertões? Que facilidades e dificuldades acarreta uma segunda tradução de um texto?

BZ: Sim, atualmente estou trabalhando na travessia tradutória do Grande Sertão e das suas muitas Veredas, e entendo o prêmio Blaise Cendrars também como incentivo para levar a cabo esta tarefa do tradutor com nova energia, coragem e vento em popa, mas sem pacto diabólico, mesmo porque Riobaldo constatou que "o diabo não há".

Pela primeira vez estou traduzindo um texto que já foi traduzido para o alemão, ou seja, se trata de uma retradução, uma nova tradução para um mesmo idioma. Além disso, esse livro já foi traduzido para outras línguas que conheço, sendo essas traduções objeto de muitas pesquisas, também das minhas. Pois essas traduções anteriores e os estudos sobre elas fazem parte, junto com a crítica literária acadêmica e jornalística, da fortuna crítica e da história da recepção. E sabemos que, querendo ou não, a leitura e, portanto, também uma tradução de um texto não pode abstrair totalmente da sua recepção, ao contrário, pois esta faz 
parte do imaginário daquele texto. Diante de outras abordagens críticas - a resenha jornalística, a análise acadêmica, seja linguística, poetológica, sociológica, filosófica, voltadas para determinados aspectos - a tradução analisa uma obra em sua integridade, elaborando uma implícita metalinguagem, convertida em obra literária paralela, um comentário contínuo. Haroldo de Campos, hermeneuticamente, chama a tradução uma forma privilegiada de leitura, pois ela entra nos "mecanismos e engrenagens mais íntimos" do texto, revelando as suas "operações formadoras". O autor de uma retradução se vê, portanto, diante da enorme chance, mas também da dificuldade de levar em consideração, de algum modo, a fortuna crítica do original, à qual pertence sua fortuna tradutória, que por sua vez formou a ideia que muitos leitores têm do original. As traduções anteriores são úteis, mas também dão trabalho e consomem tempo. São instrutivas sobretudo traduções para a própria língua do 'retradutor', e para línguas próximas, que no caso do alemão é o holandês, e aí temos a boa tradução de Willemsen.

As tarefas do tradutor são muito diferentes em Os Sertões e em Grande Sertão: Veredas, apesar do parentesco entre os dois livros, não só nos títulos, mas no contexto geográfico, social, cultural, também no vocabulário, e no embate entre civilização e barbárie, embora este apareça de modo mais indireto em Guimarães Rosa. Não só os gêneros literários são diferentes, mas sobretudo as estruturas narrativas e os estilos, pois ao passo que Euclides faz música sinfônica, para um grande público, Guimarães Rosa faz música de câmara, para um ouvinte só, que por outro lado representa a totalidade dos possíveis leitores. $\mathrm{O}$ narrador rosiano não tem um manuscrito pronto, mas formula as suas ideias e recordações ad hoc, num diálogo. Ou seja, é ou finge ser uma oralidade mais espontânea, coloquial, íntima, mais regional, mais sertaneja e brasileira, com mais elipses, e mais elementos idioletais do que em Euclides, com maior grau de hermetismo. E Euclides se dirige mais diretamente a um público internacional do que Rosa. Os procedimentos poéticos desse último não seguem as regras dos manuais poéticos e retóricos, as regras dessa linguagem, a sua morfossintaxe, são invenção de Riobaldo e do seu autor. Daí o fato de a erudição e pesquisa serem mais complicadas do que no caso de Euclides. Para entender Os Sertões é útil estudar a retórica e historiografia clássica, Heródoto, Tucídides, Cícero, Quintiliano, mas isso para estudar Rosa rende menos, pois Guimaraes Rosa tem uma linguagem muito insólita, singular, muito distante de outros autores, clássicos ou modernos, brasileiros ou não, embora os tenha lido, visivelmente, inclusive Homero, Platão, Dante, Nietzsche, Joyce. É preciso estudar os procedimentos e princípios dele, inclusive ler suas autocaracterizações para tirar daí ensinamentos e sugestões sobre a estratégia da tradução de Grande Sertão: Veredas.

RA: Então você acha que o próprio texto-fonte já lhe dá umas dicas sobre o modo de que deve ser traduzido? 
BZ: É isso mesmo. O método da tradução resulta de certa maneira do método da produção do texto que a gente quer traduzir - naturalmente com a condição de que o público da cultura-alvo seja comparável com o da culturafonte. Se um texto feito para um leitor que conhece Homero, Shakespeare, Joyce é traduzido para um público digamos infanto-juvenil, aí é outra coisa, claro. Mas no caso de Guimarães Rosa, geralmente o público internacional tem algumas afinidades, embora já haja também adaptações de Grande Sertão: Veredas até como graphic novel. Se a crítica de um texto, a reconstrução mental de suas propriedades estéticas, faz parte da tarefa do tradutor, se a tradução é crítica e criação, como diz Haroldo de Campos, e se todo texto de alta qualidade estética e por assim dizer antropológica, tem um alcance que transcende os limites da comunidade cultural e linguística para a qual foi escrito, então se pode dizer, com Benjamin, Haroldo, Berman, e o próprio Guimarães Rosa, que uma análise textual minuciosa e empática nos dá indícios da estratégia de uma tradução apropriada a esse texto. Benjamin diz que os grandes textos contêm nas entrelinhas a sua tradução virtual, e eu acredito isso. Claro que não há só uma única tradução virtual, pode haver várias, mas nem qualquer tradução é adequada, capaz de deixar transparecer as qualidades do original, que nem um palimpsesto. Rastreando minuciosamente o caminho que o autor fez ao escrever, o tradutor pode refazer esse caminho em outro idioma, aproximadamente. A traduzibilidade, e uma certa margem de manobra na tradução, está embutida no original, que nos dá balizas, avisos, recomendações sobre o modo de que ele pode ou 'quer' ser lido por estrangeiros, e sua leitura é um primeiro passo para a tradução. Um texto não apenas tem seu "leitor implícito", como diz Wolfgang Iser, mas, a meu ver, tem também seu "tradutor implícito", prefigurando e pedindo sua reconfiguração em outro idioma. O potencial interpretativo e expressivo desse idioma-alvo deve ser aproveitado, com a maior flexibilidade possível, para se adequar e se assimilar ao texto e à língua de partida e expressar as suas principais qualidades semânticas-estéticas. Algumas características do texto são realçadas, outras ficam no segundo plano, é um jogo de perdas e ganhos.

RA: São conhecidas as cartas que Guimarães Rosa trocava com seus tradutores, o que podemos aprender do dialogo deles em relação à tradução?

BZ: Justamente, Guimarães Rosa, além de grande escritor, foi um poeta doctus, e alguém que tinha ideias muito claras sobre estratégias tradutórias. Além disso, ele mesmo tinha experiência como tradutor, traduziu, ainda como estudante de medicina, textos científicos, e mais tarde até um romance de um escritor canadense, Fred Bodsworth, Last of the Curlews, $O$ último dos maçaricos, em que os personagens são aves, uma transcriação muito cuidadosa, em que a gente pode apreciar não só a reconfiguração poética, mas também a pesquisa ornitológica que Guimaraes Rosa fez. Então ele sabia muito bem o que era tradução. E tinha uma clara ideia daquilo que eu chamo de tradutor implícito 
que ele queria explicitar para os seus tradutores reais. Rejeitava "expressões domesticadas e acostumadas", queria "chocar e estranhar" o leitor, odiava chavões e clichês, frases feitas, e preferia um estilo paratático para dar autonomia às partes da fala. Queria que cada palavra, cada sintagma, cada oração reverberasse de modo especial, sugestivo, chamando atenção para si, para a trama e os personagens, para o sertão e para o mundo, contra hierarquias sintáticas e lógicas. Queria ser opaco, misterioso, sugestivo, através de palavras e colocações inusitadas, elipses sintáticas e lógicas, certa abstração na figuração de acontecimentos, personagens, paisagens e objetos, para aumentar a alusividade. O leitor devia ter muita liberdade para preencher as 'lacunas' do texto com a sua imaginação. Ele estabelecia uma parceria entre autor e tradutor, já que queria que os tradutores assumissem os mesmos princípios e procedimentos estéticos dele, pois ele não fazia uma nítida distinção, ao nível da confecção linguística, entre o criar e o recriar.

As ideias estéticas e tradutórias do próprio autor têm muito em comum com concepções da hermenêutica e dos Estudos da Tradução, de Schleiermacher, Berman, Benjamin, Venuti, dando preferência - contra práticas assimiladoras, etnocêntricas, domesticadoras - a estratégias estranhadoras, reconfiguradoras, estrangeirizantes. Mas por outro lado ele sabia que resgatar completa e perfeitamente em outro idioma a "maneira-de-dizer" - expressão do próprio Guimarães Rosa - do original era difícil ou até impossível, principalmente nos anos sessenta do século XX. Então acabou aceitando e até elogiando traduções que no fundo contrariavam os seus próprios princípios poéticos.

RA: Qual a sua opinião sobre a primeira tradução de Grande Sertão: Veredas para o alemão? E em que você pretende se diferenciar dela, na meta e na estratégia?

BZ: É um pouco delicado eu falar sobre a obra de um grande predecessor, amigo de Guimarães Rosa, muito elogiado por ele, um importante embaixador por assim dizer da literatura brasileira e das literaturas ibero-românicas na cultura de língua alemã. Por outro lado, traduzir para o alemão como ele fazia, hoje em dia, ninguém o faz, a partir de língua nenhuma, em se tratando de literatura de alto nível estético. Os padrões tradutórios têm mudado bastante. Meyer-Clason foi representante de uma época em que, na prática literária, pouco se distinguia tradução de adaptação e paráfrase, sendo o tradutor senhor quase absoluto do texto-alvo. Tinha que obedecer apenas às orientações dos editores, à expectativa do público, ao seu próprio gosto estético, não havia crítica da tradução, não havia 'advogados' do original cobrando lealdade para com ele. Meyer-Clason transpôs o estilo rosiano, extremamente distante do português padrão, para um alemão fluente, corrente, bonito, colorido, imagético, sonoro, sem qualidade diferencial nenhuma com respeito ao alemão padrão, cumprindo inteiramente as expectativas do público com relação a ficcionistas latinoamericanos, e descumprindo quase inteiramente os princípios poéticos de 
Guimarães Rosa. Um estilo que poderia ser o de García Márquez, de Jorge Amado, de Adonias Filho e de muitos outros autores vertidos pelo mesmo tradutor. Assim, o leitor não pode conhecer da fala pausada, tateante, espontânea de Riobaldo, da sua coloquialidade de fazendeiro meditativo, que já foi jagunço, linguagem cheia de infrações contra a norma culta e da lógica discursiva, cheia de elipses, anacolutos e laconismos, aquela oralidade ao mesmo tempo popular e sofisticada, regional e filosófica, sempre absolutamente nova e poética. Essa tradução alemã justamente faz o contrário de tudo o que Guimarães Rosa queria, ela não choca, não estranha, não é opaca ou enigmática, não é metafísica, ela preenche elipses gramaticais e lógicas, usa e abusa de lugares-comuns e provérbios conhecidíssimos. Por outro lado, pratica numerosas vezes uma gíria urbana às vezes até vulgar, que lembra romances populares sobre a Segunda Guerra Mundial, um registro totalmente alheio ao português de Riobaldo. Pois este, apesar de pouca escolaridade, evita qualquer vulgaridade, sendo até de uma notável delicadeza nos registros que usa, que oscilam entre coloquialidade cotidiana e sublime. Mais grave no procedimento do tradutor talvez seja a tendência ilustrativa, ornamental e amplificadora ao relatar situações e ações, pois o tradutor parece querer corrigir um certo abstracionismo do autor, um quase ascetismo na pintura da realidade, inventando detalhes da trama e dos personagens que não aparecem no original.

Uns exemplos. Logo no inicio aparece um bezerro disforme que os homens de Riobaldo matam, o que é expresso de uma maneira lacônica: "Mataram". Isso vira em alemão, retrotraduzido: "Eles o mataram a pancadas imediatamente", ou seja, o tradutor acrescenta um advérbio e concretiza o modo de matar, 'corrigindo' o relato relativamente sóbrio e abstrato do autor. Quando o Riobaldo brasileiro fala "O acampamento da gente parecia uma cidade", o seu xará alemão fala, retrotraduzido: "O acampamento zunia como uma colmeia", o que em alemão é uma imagem bastante usual, um lugar comum, bonito, mas não é Guimarães Rosa. "Eu tinha o medo imediato" vira "Eu tinha medo das raízes do cabelo até as pontas do pé". A morte do marido de Maria Mutema é narrada no original com pouca concreção, mas com uma redundância, além de uma quádrupla aliteração: "morreu, amanheceu morto de madrugada", o que parece quase um oximoro ou paradoxo, como se dissesse: 'Acordou morto'. O tradutor alemão ignora a redundância e por outro lado comete uma amplificação, inventando uma informação adicional: "de manhã ele estava deitado morto na cama". Claro que provavelmente aquele homem costumava dormir em uma cama, ainda que houvesse também a alternativa da rede; de qualquer forma, se o autor prefere silenciar aqui o lugar exato do sono e da morte do personagem, retratando a realidade com escassas e sugestivas pinceladas, o tradutor não deveria acrescentar detalhes concretos, visíveis, palpáveis, dando à sua representação da realidade um caráter mais plástico, mais ilustrativo, mais realista - e mais tradicional. No início da primeira travessia do Liso do Sussuarão, Riobaldo resume em concisão genial o choque que esse deserto the 
proporciona: "Vi a luz, castigo". Em alemão isso aparece barroquizado: "Eu só vi luz, dolorosa, e foi como um castigo". Em um texto poético a sequência dos sintagmas, das ideias e imagens faz parte da configuração estética, aspecto que o tradutor alemão ignora muito além das coerções gramaticais da língua alemã. As permanentes infrações do tradutor contra a poética condensadora, elíptica, alusiva de Guimarães Rosa têm uma contrapartida no aplainamento de aparentes redundâncias, como por exemplo na recorrente expressão rosiana "homem humano", que perde o seu adjetivo na versão alemã. Quem deu licença para isso ao tradutor? "Homem humano" é muito sugestivo, pois o leitor justamente se pergunta o que poderia significar essa duplicação léxica e semântica, uma figura etimológica. Como um tradutor pode eliminar esse e outros recursos estilísticos? Isto acontece milhares de vezes na tradução, imagine. Outro problema é a tendência para ignorar isotopias, palavras-chave que reaparecem em determinados trechos do livro, guiando a leitura e estruturando a massa do texto. Uma delas é "veredas", que no texto alemão é traduzido por meia-dúzia de termos muito diferentes, de modo que leitor não tem a chance de notar e seguir o papel estrutural e poético desse termo, concreto e simbólico, que já aparece no título, ou seja, as veredas perdem a sua identidade. Balanço: a primeira tradução alemã é muito boa no sentido de seguir o modelo tradicional das "belles infidèles". Mas isso significa que, contrariando a poética rosiana, adapta o texto ao suposto paladar dos leitores alemães da época, sem lhes dar a chance de se formar uma ideia da feitura estética do original.

RA: Observando a tradição de traduções de Grande Sertão: Veredas, pode-se dizer que há uma evolução nas estratégias de tradução? Será que uma tradução cheia de palavras e construções estranhas vai ser aceita pelo público de língua alemã?

BZ: Talvez tenha sido inevitável familiarizar, quatro décadas atrás, o público alemão com a obra inovadora e singular de Guimarães Rosa diminuindo drasticamente essa novidade e singularidade. Mas agora, acho, o texto rosiano merece ser "transcriado", como diria Haroldo de Campos, sem censura, sem eliminação nem acréscimo de nenhum elemento expressivo, emotivo ou ideológico - na medida do possível, claro — , para permitir ao leitor de língua alemã rastrear, conhecer, vivenciar algo da polissemia, força sugestiva, mistura de oralidade popular, erudição filosófica e experimentalismo estético do original, algo do riquíssimo potencial de significados que está à disposição do leitor do original, acrescido de significados sugeridos pela cultura e pela fantasia do leitor da cultura de chegada. Pois no caso de textos poéticos é importante traduzirmos não só o designado, mas o modo de designar as coisas, como diz Benjamin. Pode-se vislumbrar, no decorrer de mais de meio século de esforço tradutório voltado a Grande Sertão: Veredas, uma tendência para um crescente respeito pela poética rosiana, graças a maiores facilidades de pesquisa, e sobretudo graças a uma crescente disposição, da parte de leitores, críticos e editores, para aceitar 
traduções com elevado grau de 'choque' e 'estranhamento'. Hoje em dia, as chances talvez sejam melhores do que nunca para reconfigurar, aproximadamente, o insólito estilo rosiano, seu jogo ambíguo entre revelação, alusão e opacidade, sem desanimar o leitor, oferecendo-lhe uma qualidade que Paul Celan reivindica de toda tradução poética: 'fremde Nähe' - 'proximidade alheia'. 


\section{ENTREVISTA CON BERTHOLD ZILLY}

"Euclides me hizo traductor"

Berthold Zilly, nació en 1945 en Danndorf, en el norte de Alemania. Es doctor en Filologias Románica y Germánica, con tesis sobre Molière, por la Freie Universität Berlin, en la cual dio clases de letras latinoamericanas (1974-2010), lo que también hizo en la Universität Bremen (2004-2010). Impartió cursos intensivos e hizo ponencias en universidades latinoamericanas, norteamericanas y europeas. Siempre se comprometió también con la extensión cultural, colaborando intensamente con la difusión de la cultura brasileña en Alemania. Publicó numerosos artículos, reseñas, ensayos sobre literatura brasileña y argentina, con dos enfoques: literatura-historia; literatura comparada-traducción. Llevó clásicos de América Latina y de Portugal al alemán, Civilización y barbarie, de Domingo F. Sarmiento, Os sertões, de Euclides da Cunha, Memorial de Aires, de Machado de Assis, Triste fim de Policarpo Quaresma, de Lima Barreto, Confissão de Lúcio, de Mario de Sá-Carneiro, Lavoura arcaica, de Raduan Nassar. Practica la traducción como parte integrante de la enseñanza y de la investigación de lenguas y literaturas extranjeras y de los estudios interculturales. Ha recibido diversas condecoraciones en Brasil y en Alemania, la más reciente en agosto de 2017, en la UERJ, el premio Blaise Cendrars, que otorga anualmente la Associação Brasileira de Litreratura Comparada (Abralic), "como reconocimiento a especialista extranjero por su contribución al estudio de literatura brasileña en clave comparada". Actualmente, es profesor visitante en el posgrado en estudios de traducción, de la Universidad Federal de Santa Catarina. 
Claudia Silveyra D’Ávila (CSDA): Empezando por su más reciente premiación, ¿cómo se siente usted tras la obtención del premio concedido por la ABRALIC?

Berthold Zilly (BZ): Bien, en primer lugar, lo que pienso y siento es gratitud por el hermoso homenaje de la Universidade do Estado do Rio de Janeiro, la UERJ, y por haber sido contemplado con ese valioso premio, el premio Blaise Cendrars. Gratitud también a la Abralic, su Mesa Directiva, y a su presidente João César por el honor y reconocimiento de mi trabajo en pro de la difusión de la cultura brasileña, y a Johannes Kretschmer por las palabras de presentación con que me insertó, por decirlo así, en la tradición de los viajerosinvestigadores europeos que vinieron a Brasil, desde el siglo XIX. Estoy agradecido al equipo que colaboró en la realización de este magnífico congreso, agradecido a toda la UERJ, a los profesores, funcionarios y estudiantes que hicieron posible este evento, trabajando voluntariamente, con gran abnegación, pese a la grave crisis y a las condiciones tan adversas por las cuales está pasando la universidad. Me considero honrado también por el nombre del premio que remite a un gran poeta, escritor, viajero, viajero, mediador cultural suizo-francés, con quien, todas las proporciones guardadas guardando todas las proporciones, siento afinidades: la pasión por la cultura y por la gente de Brasil, considerado por él y por mi otra patria, el deseo de construir puentes entre Brasil y Europa, y también la alta estima por la actividad traductiva. Cendrars sugirió traducciones de literatura brasileña al francés, y él mismo emprendió algunas: tradujo, por ejemplo, una importante novela sobre la Amazonia, A selva, de autor portugués, Ferreira de Castro. Tenemos en común también la admiración por Euclides Acuña, cuya obra prima, Os sertões, quiso traducir Cendrars, sin, con todo, encontrar la oportunidad para ello. En eso yo he tenido más suerte, cumpliendo de cierto modo la intención del patrono del premio, aunque con otra lengua meta.

Mi agradecimiento se extiende a Brasil y a la cultura brasileña que además de la cultura alemana y la francesa - me ha civilizado, fascinado, formado humana, estética intelectualmente, desde hace más de medio siglo. Sin la cultura brasileña sólo sería el intelectual que soy, tampoco sería traductor, no tendría los amigos que tengo, sería probablemente más cerebral, más especializado, más eurocéntrico, quizás menos interesado en ver de un modo distinto aspectos universales de la condición humana. Hago mías las palabras del historiador francés Fernand Braudel: ${ }^{4}$ "Yo me hice inteligente yendo a Brasil. El espectáculo que tuve ante los ojos era tal espectáculo de historia, tal espectáculo

\footnotetext{
${ }^{4}$ LIMA, Luís Corrêa. Fernand Braudel (1902-1985). In: Os historiadores: clássicos da história, v. 2: de Tocqueville a Thompson. Petrópolis, Rj: Vozes: PUC-Rio, 2013, pp. 283-284.

Une leçon d'histoire de FERNAND BRAUDEL. Châteairvallon. Journées Fernand Braudel 18, 19 et 20 octobre 1985. Les Editions Arthaud, 1986, Paris. Tous droits réservés. I.S.B.N. 2-70030557-4. Imprimé en France. In: <https://dlscrib.com/queue/une-lecon-d-39 histoire 58c96e91d c0d600a3b339029 docx?queue id=59abda9fdc0d603f3b568ee4>.
} 
de gentileza social, que comprendí la vida de otra manera." [Así reza la cita del libro de Luís Correa Lima; he aquí el original: "Je suis devenu intelligent en allant au Brésil. Le spectacle que j'avais sous les yeux était un tel spectacle d'histoire, un tel spectacle de gentillesse sociale que j'ai compris la vie autrement."]

Estoy muy contento de que el premio me haya sido entregado en el congreso de la Abralic, pues fue un brillante evento intelectual, cultural y académico de una importante asociación profesional que hace brillar las letras brasileñas en el mundo, justamente aquello a lo que siempre intenté contribuir. Y también es un encuentro humano, una congregación, una confraternización, palabras sólo imperfectamente traducibles en alemán. Parece un cliché, pero tiene un fondo de verdad, es decir, la idea de cordialidad, de la afectividad, del carácter personal de la relaciones humanas en Brasil, acerca de las cuales hay observaciones en los relatos de viajeros históricos, manifiestos modernistas, en los ensayos de Gilberto Freyre, Sérgio Buarque de Holanda, Stefan Zweig, Roberto da Matta, Pedro Monteiro, João Cezar de Castro Rocha y muchos otros. Tal vez una actitud así no siempre sea compatible con el imperativo categórico de Kant, pero relaciones compañerismo y simpatía, acompañadas de un abrazo, llegarían a agradar al filósofo de Königsberg.

RA: ¿Es decir que usted tiene una relación no sólo académica con Brasil?

BZ: Eso mismo. La cultura brasileña me parece interesante y simpática, porque, entre otras cosas, aún es bastante visceral, emotiva, principalmente en sus estamentos más populares, además de ser también racional e intelectualizada, naturalmente. Ella vive más en contacto con las bases biológicas y psíquicas del ser humano y de la vida social, el cuerpo, la sensorialidad, la voz, el temperamento, pero también con la espiritualidad, es decir, es una cultura atenta a lo físico y a lo metafísico. En la literatura erudita, digamos, eso se manifiesta en la importancia que tiene la cultura popular, la oralidad, el ritmo, la sonoridad, la gestualidad, también el diálogo con otras artes y prácticas sociales, con la música, la danza, el teatro, la religiosidad. En su conocido ensayo El narrador, Walter Benjamin enfoca la figura del contador de historias, valorizando el origen y la dimensión popular, oral, comunicativa de la tradición literaria, principalmente del cuento y de la novela. Esa es una dimensión en Brasil está más presente aún que en Alemania; por ejemplo, basta leer y oír a Guimaraes Rosa. A Benjamin le habría gustado mucho la literatura brasileña, y la literatura latinoamericana en general. Pero no quiero decir con eso de que cultura brasileña sea predominantemente emotiva, sensorial, lúdica, mágica, mítica, popularartística, de cierta manera premoderna, y que la europea sea sublimada, cerebral, racional, moderna, científica; pensar así sería otro cliché, Brasil sería la tierra de lo dionisíaco y Europa la tierra del apolíneo. No es tan simple, no es así. Es verdad que, tradicionalmente, los europeos tendían a una visión un poco simplificadora: Brasil suministraría la materia prima cultural; Europa 
suministraría el análisis y la teoría para interpretarla. Aun Cendrars tenía una pizca de ese pensamiento, aunque fuera amigo de los modernistas y admirara el crecimiento febril, la modernidad y el cosmopolitismo de São Paulo. Por otro lado, el filósofo alemán Max Bense, otro gran amigo y conocedor de Brasil, interlocutor de los poetas concretos, admirador de Lúcio Costa y de Niemeyer, llegó a percibir la moderna cultura brasileña como cartesiana, una visión ciertamente unilateral, pero no equivocada. Ya hace tiempo que la universidad brasileña hace investigación de alto nivel, formando excelentes profesionales, pese a todos los problemas que conocemos, principalmente con los más recientes cortes de rubros.

RA: ¿Entonces a usted le parece cualquier definición de la cultura brasileña sería simplificadora y conduciría a clichés?

BZ: Sí, aunque sea siempre una tentación determinar cuáles son las cualidades o los problemas de una cultura, y de una nación. Esas corrientes del pensamiento sobre el supuesto carácter nacional y la psicología de los pueblos han tenido alguna coyuntura, antes de la Segunda Guerra Mundial pero definiciones de una cultura, principalmente definiciones unívocas, son arriesgadas o imposibles, sobre todo cuando se habla de Brasil, un país continente, y pueden fomentar un nacionalismo soberbio o un desprecio del otro y de sí mismo. Siempre hay un abanico amplio y múltiple, y aun contradictorio, de características de un país y de su cultura, hay diferencias y cambios sociales, regionales, históricos; mucho depende también del punto de vista personal ideológico del observador. Para ver con más claridad esas cuestiones me ha sido muy valioso el libro de Dante Moreira Leite: $O$ caráter nacional brasileiro [El carácter nacional brasileño], que justamente deconstruye dicha concepción. De cualquier manera, Brasil es una gran Kulturnation, una nación caracterizada culturalmente, en un sentido muy amplio, porque aquí la tradicional cultura popular, la cultura de masas, erudita, no están separadas y estancadas, sino que viven transiciones y mezclas productivas. En Alemania, por el contrario, hay una distancia mucho mayor entre la llamada E-Kultur (cultura erudita, "seria") y U-Kultur (cultura de entretenimiento). A diferencia de Alemania, donde se dio una cultura nacional sin un estado nacional, 200 años atrás, Brasil heredó un estado, teniendo que formar enseguida una cultura nacional, lo que hace hasta el día de hoy con éxito, de modo muy productivo y creativo, gracias a sus raíces múltiples, indígenas, africanas, europeas y al mestizaje entre ellas. Asimismo gracias al cultivo de tradiciones, y por otro lado a la apertura a innovaciones, nuevos productos, técnicas y hábitos, incluso en el ámbito intelectual y artístico. También a la apertura al diálogo con otras culturas. Los brasileños siempre sabían [¿supieron?], más que los alemanes, que la cultura no es un patrimonio y un acervo fijo, y que es difícil definir una Leitkultur, como desean políticos conservadores en Alemania, es decir, un conjunto de valores culturales y comportamentales que serán asumidos por los inmigrantes, algo fijo que se aprende, se tiene y pronto. Ocurre que las culturas siempre están diferenciándose y mezclándose, formándose y transformándose, y nunca son homogéneas, de modo que las diferencias internas forman parte de ellas. Felizmente, hoy día, en los estados democráticos, la total homogeneidad cultural ya no es un valor central, sería incluso un empobrecimiento. ¿Qué es lo que forma la riqueza y la especificidad de Brasil en el plano mundial? No son los commodities, sino la cultura brasileña con su diversidad y vitalidad, con sus actividades y producciones artísticas, 
costumbres, cocina, deporte, y también con su producción intelectual y científica, por ejemplo en los estudios literarios y de traducción, que conozco en primera mano.

RA: ¿Cuando nació la relación con la cultura brasileña y qué fue lo que más le interesó?

BZ: todo empezó en los años 60 del siglo XX, y fue desde el inicio una relación múltiple, con la cultura, y con personas, con el cinema novo, que a esa altura realmente era nuevo, con la literatura especialmente la nordestina. En 1966, yo estaba estudiando literatura francesa en la universidad de Caen, en Normandía, y allí vi Vidas secas, de Nelson Pereira dos Santos, Deus e o Diabo na terra do sol, de Glauber Rocha, Os fuzis, de Ruy Guerra, $O$ cangaceiro, de Lima Barreto, del cineasta con ese nombre, empecé a leer literatura brasileña, sobretodo a Graciliano, en francés o en alemán, empecé a estudiar portugués, y al mismo tiempo hice amistad con estudiantes brasileños, sobre todo del Nordeste, y también: cherchez la femme. Por lo tanto, aunque pueda parecer extraño, la región que más me fascinó fue el Nordeste, y dentro del Nordeste el sertón, aunque yo haya leído a partir de allí también autores que hablan más de la Zona da Mata, de las plantaciones de azúcar, del cacao, de la ciudades de la costa, Recife, por ejemplo, José Luis, Amado, Josué de Castro, Jorge de Lima, incluso para conocer personalmente a los autores clásicos nordestinos: Gilberto Freire y José Américo de Almeida, en 1968, cuando vine a Brasil por primera vez con un grupo de estudiantes alemanes interesados en conocer problemas del tercer mundo, como se decía en aquel momento. Ese viaje, en plena dictadura militar, me marcó y me empujó definitivamente hacia los estudios brasileños y latinoamericanos. Tuve el enorme privilegio de estudiar un semestre que parece poco, pero para mí fue decisivo, en la USP en 1969, y así conocí a Antonio Candido, con quien hice dos cursos, de los mejores que hice en mi vida. También aprendí mucho con Aderaldo Castello y Garbuglio. Antonio Candido, en São Paulo, y Peter Szondi, en Berlín, fueron los profesores que más me marcaron, aunque haya estudiado directamente con ellos por muy poco tiempo, infelizmente.

RA: Su formación es en Letras Románicas, principalmente francesa. ¿Cómo combinó usted eso con su dedicación a la cultura brasileña y a su divulgación?

BZ: Bueno, he tenido una formación bastante tradicional, filológica lato sensu, pues en la universidad alemana el término filología alcanza no sólo la filología tradicional, etimología, historia de lenguas emparentadas, como las romances, por ejemplo, edición crítica de textos, etc., sino que tiene un sentido más amplio. Nosotros somos o deberíamos ser filólogos en el sentido original del término en griego: "amigo de la palabra", también "amigo del logos", estudioso de la palabra escrita y hablada, de la poética, de la retórica, de la forma lingüística del pensamiento, de textos configurados estéticamente. Y el amigo de la palabra sabe que las palabras tienen carga emocional, ideológica, política. Usar lenguaje es una manera de actuar, que implica responsabilidad, un compromiso con el logos, la razón, la justicia, el humanismo. Así, la filología se acerca a la historia y a las ciencias sociales, también al derecho, a la filosofía, un poco a todo, como la retórica en la antigüedad.

Estudié filología románica y también la germánica, pese a mi tendencia hacia el Fernweh, la añoranza de lo lejano. Pero siempre aprecié, aunque críticamente, mis orígenes, la cultura alemana. Creo que quien estudia extranjero, al otro, lo ajeno, hace bien en conocer y estudiar lo propio también para discernir mejor las cualidades de lo ajeno, y para establecer un diálogo intercultural. Este tiene ciertamente una de sus formas más intensas, más sofisticadas y más duraderas en la traducción. Enseñé 
diversas lenguas —alemán, francés, portugués, español- dentro y fuera de la universidad, y parte de las respectivas literaturas, también como fuente de conocimiento sobre las respectivas civilizaciones, usando a veces la traducción como herramienta de comprensión y de control del aprendizaje. Hice doctorado en literatura francesa, pero la mayor parte del tiempo fui profesor de culturas latinoamericanas, con énfasis en el Brasil, durante más de 36 años en Alemania, y después fui invitado a ser profesor visitante en la Universidade Federal de Santa Catarina, en la isla de Santa Catarina, donde he estado enseñando Estudios de Traducción y también he dado clases de literatura alemana. Creo que mi formación y experiencia filológica me ha sido bastante útil para integrarme a la cultura brasileña. Y acercarse a Brasil a través de Francia es volver a recorrer de cierta forma un camino histórico de la literatura brasileña, para la cual las letras francesas fueron modelo, durante un segundo un siglo y medio.

RA: Como profesor visitante en el área de Estudios de Traducción, ¿cómo ha encontrado la posición de la traducción en la universidad brasileña?

BZ: La literatura brasileña me ha llevado a la traducción literaria y la Universidad brasileña me ha llevado, de una manera profunda, a los Estudios de Traducción. El traducir y el reflexionar sobre el traducir ocupan un espacio importante en la universidad brasileña, distintamente de la alemana. El Postgrado en Estudios de Traducción, en Florianópolis, por ejemplo, congrega unos 30 profesores de los diversos ramos de las letras, de la lingüística, de la filosofía, de la antropología, del teatro, etc., alrededor de la traducción, siendo, por lo tanto, un programa interdisciplinario, que de forma más o menos parecida existe en distintas otras universidades brasileñas. La traducción y la investigación sobre traducción tienen un lugar reconocido importante en la academia, con excelentes teóricos que generalmente también son traductores, es decir, tienen una buena integración entre práctica e investigación. En Alemania, por el contrario, con poquísimas excepciones, la traducción y la reflexión traductológica tienen una posición marginalizada en la academia, aunque existan excelentes especialistas, de todos modos bastante aislados y desperdigados. El traducir ni siquiera se considera una producción académica, se considera una actividad más bien técnica, o bien artística, de acuerdo con el tipo de texto; de cualquier forma no rinde créditos a la carrera de un profesor, a no ser, en la filología clásica, cuando se traduce y comenta un autor griego, por ejemplo. El relativo desprestigio de la traducción en la universidad alemana podría sorprender, pues hace siglos la traducción y la reflexión al respecto, muchas veces combinadas con el pensamiento hermenéutico en la filosofía, en la teología, en las letras, en el derecho, ocupa y preocupa a las mejores inteligencias alemanas; basta pensar en Luther, Schleiermacher, Wieland, Lessing, Goethe, Hölderlin, los hermanos Schlegel, Tieck, Benjamin, Gadamer y muchos otros que son estudiados hasta la actualidad, también en Brasil. En la universidad brasileña la traducción y los estudios de traducción están bien institucionalizados, y tienen un alto nivel, de modo que alguien como yo aquí tiene excelentes interlocutores y excelentes condiciones de trabajo.

RA: Berlín es un importante punto de encuentro para personas interesadas en América Latina y para los mismos latinoamericanos. ¿Eso le ayudó a cultivar su apego al Brasil?

BZ: Sí, sin dudas, en ese sentido Berlín también me formó y me dio la oportunidad de ser algo como un agente cultural. Ese es un aspecto poco documentado de mis actividades, y como no hay currículo Lattes en Alemania yo tampoco lo registré. 
Pero fue muy enriquecedor para mí personal y profesionalmente, y para algunas otras personas también, espero. Pues desde 1969, después de volver de una estadía de un año en Brasil, siempre organicé o ayudé a organizar algo, o me invitaron, como moderador, traductor, participante, de alguna manera, en centenas de eventos culturales y académicos alrededor de la cultura brasileña: lecturas, ponencias, presentaciones musicales, obra de teatro, mesas redondas, exposiciones, proyecciones de filmes. Me gusta organizar encuentros y cooperar con personas en eso. Recibí artistas, periodistas, profesores brasileños en Alemania... Me acuerdo, por ejemplo, que fui intérprete en una entrevista colectiva de Eduardo Coutinho en el festival de cine de Berlín, cuando se estrenaba Cabra marcado para morrer; encontré números intelectuales en Berlín: Paulo Singer, Miriam Goldenberg, Tereza Raquel, João Antônio, Loyola Brandão, Ubaldo Ribeiro, Bernardo Carvalho, Antonio Callado, Rafael Cardoso, Roberto da Matta, Rubem Fonseca, Evando Nascimento, la pareja Freitag-Rouanet, Antônio Torres, Silviano Santiago, Ligia Fagundes Telles, Isabel Lustosa, Raquel de Queiroz, Zé Celso, Roberto Schwarz, Arnoni Prado, Roberto Ventura, Darcy Ribeiro, Karim Ainouz, Susana Amaral, Fernanda Montenegro, Haroldo de Campos, João Luiz Lafetá, João Klug, João Cezar... Esos son nombres que recuerdo ahora, podría sentar una centena más. Hubo eventos en universidades, en la embajada brasileña, en ferias del libro, en librerías, casas de cultura, también en otras ciudades alemanas y europeas. Desde 1995 hasta 2005 existía en Berlín, por iniciativa de Sergio P. Rouanet, el ICBRA, Instituto de Cultura Brasileña en Alemania, en el cual fui bastante activo. La presencia cultural de Brasil en el exterior, como cualquier trabajo de extensión cultural, vive también a través de innúmeros pequeños eventos, y para ellos el entusiasmo de activistas culturales es fundamental. Felizmente Brasil tiene en Alemania, y en Europa de un modo general, muchos amigos, que ayudan gustosos a divulgar la cultura brasileña.

RA: No todos son nombres de literatos o críticos literarios. ¿La interdisciplinariedad forma parte de su formación y de su trabajo intelectual?

BZ: Sí, claro, trabajé en un instituto interdisciplinario, el Lateinamerika-Institut de la Freie Universität Berlin, la FU, donde se enseña e investiga economía, ciencias políticas, antropología, sociología, historia, literatura, todo con el denominador común de América Latina. Siempre he tenido contacto con colegas y estudiantes de otras áreas, a veces incluso con estudiantes de medicina, teología, derecho, historia del arte. También daba clases de lengua portuguesa y de civilización brasileña a estudiantes de economía, sociología, antropología, leyendo textos de esas áreas con ellos. Conversaba con colegas de la sociología, historia o de otras áreas sobre los más diversos temas no literarios, lo que me facilitaba contextualizar la literatura. No perdí el contacto con los estudios germanísticos, por ejemplo como miembro de tribunales de doctorado de estudiantes brasileños, con tesis sobre literatura alemana. También me marcó el movimiento estudiantil de los años 60 y 70, cuando era casi obligatorio leer a Marx, Freud, Lukács, Benjamin, William Reich, Max Weber, a la escuela de Frankfurt, especialmente a Adorno, también a Marcuse, la Teoría de la Dependencia, esta un aporte importante de América Latina para pensar los orígenes y causas de la pobreza y de las desigualdades del mundo. Todo eso es muy bueno para un crítico literario, pues la literatura, principalmente a partir del Naturalismo de fines del siglo XIX, puede hablar de todos los sectores de la realidad, todos los temas, dialogando con todas las actividades artísticas, científicas y prácticas. El crítico literario y el traductor tienen que ser intelectuales abiertos, polivalentes, enciclopédicos, dispuestos a integrarse en casi 
todos los campos del saber humano; ese sería el ideal de cualquier manera. En Brasil, en América Latina, siempre ha tenido gran importancia el ensayo, género que pertenece a la literatura, pero también el pensamiento social e histórico, eventualmente incluso al pensamiento científico, a la crítica literaria y cultural. Véase también la crónica, en la cual Brasil es casi campeón mundial, y que oscila entre el periodismo y la literatura.

Bien, todo eso me dio un contacto intenso, concreto, íntimo con diversos aspectos de la realidad brasileña, lo que es bastante útil para quien hace traducción. Como traductor, encuentro también el problema de que cualquier texto tiene una especie de subtexto, conocimientos y actitudes que el autor presupone en los lectores supuestos de todo tipo, intertextuales y extra textuales - sin los cuales es difícil entender el texto. Cuando Machado de Assis, o más bien, su narrador, Conselheiro Aires, habla sobre el 13 de mayo, sobre el cementerio São João Batista, sobre la Rua do Ouvidor, la Guerra del Paraguay, el Morro do Castelo, el espiritismo, la cuestión militar, Camões, el traductor tiene la tarea, primero, de investigar para entender esos textos, de suministrar al lector extranjero los necesarios conocimientos intertextuales y extratextuales, a través de paratextos contextualizado es sobre temas literarios, geográficos, históricos, sociológicos y así en adelante, dependiendo de las áreas tematizadas de la realidad.

De modo general, creo que son esas las dos vertientes principales de mi perfil intelectual y de mi trabajo, de mi acercamiento a la literatura: la vertiente filológica, literaria, estética, comparatista, por un lado, y la histórica, sociológica, política, por otro. Creo que las dos se complementan, pues el texto es un hecho estético, para ser contemplado en su autonomía, pero también un hecho social, para ser contemplado como expresión, interpretación de la realidad extraliteraria y aún como un elemento constitutivo de ella.

RA: Volviendo al aspecto afectivo de su trabajo, que involucra también la relación entre objetividad y subjetividad del investigador con respecto al objeto estudiado: ¿ayuda o perjudica amar el objeto de estudio?

BZ: Es una buena pregunta y va mucho más allá de los estudios literarios o de la traducción, pues me parece difícil que uno se dedique años sin pausa a una actividad que le sea indiferente, hoy incluso desagradable. Lamentablemente eso ocurre a muchos trabajadores en el mundo entero, en las fábricas, en el comercio, en la agricultura, es decir, muchos hacen un trabajo alienado, un trabajo visto solo como un mal necesario. El científico, el intelectual, el profesor, generalmente tienen más posibilidades de que les guste el trabajo que hacen, identificarse con él. Pero necesitan un fuerte interés cognitivo, una curiosidad, un cierto cariño por la disciplina en la que trabajan y también por los asuntos que investigan y enseñan. Ese interés debe ser por un lado objetivo, libre de pasiones, sine ira et studio, como decían los romanos, con cierta distancia, para poder ver críticamente todos los aspectos de una cuestión, de un tema, de un objeto, de un individuo o de un grupo. Pero es bueno también, por otro lado, que uno, como intelectual y académico, tengo una motivación emocional, que puede ser simpatía, o incluso empatía, eso es bueno para un acercamiento hermenéutico, intentando rastrear y rehacer el proceso de producción y génesis de una obra, de un acontecimiento, o de una corriente histórica o cultural, dentro de su contexto social y mental. Excepcionalmente, incluso una antipatía contra el objeto de estudio, contra una dictadura, contra guerras, contra una retórica mentirosa puede ayudar también el proceso cognitivo, de cualquier forma una emoción que nos dé energía mental para un largo trabajo de investigación 
que exige paciencia y esfuerzo. Sin una cierta relación afectiva y moral, por ejemplo, con el texto, sus personajes, o elementos de la trama, el estilo, es difícil sumergirse en una obra y convivir con ella, ver cómo funciona, como ejerce su impacto, cuál es su potencial de significados en otra cultura. He tenido la gran suerte de hacer de mi pasión mi profesión, algo que me gusta hacer desde niño: leer, hablar, discutir sobre lenguas y literaturas e ideas expresadas en ellas. Creo que lo que no me falta es curiosidad, placer, quizás incluso pasión por la literatura general, y especialmente por la literatura brasileña en su diálogo con otras literaturas.

Ahora, la cuestión de la subjetividad y objetividad, es "ein weites Feld", un campo vasto e inagotable, para citar una expresión de Theodor Fontane e Günter Grass. En las ciencias humanas, la objetividad total es imposible, pero uno puede y debe aspirar a la verificabilidad o por lo menos a la plausibilidad intersubjetiva de nuestras investigaciones, reflexiones e interpretaciones, para que nuestros interlocutores o lectores puedan entender, respetar y quizás incluso aceptar y mejorar nuestro razonamiento, pues la verdad, en última se cristaliza en un proceso colectivo, de diálogo, controversia y cooperación.

Hablando de mi subjetividad, siempre me quedé fascinado con figuras como el personaje principal de Triste fim de Policarpo Quaresma, de Lima Barreto, que traduje al alemán. Él es un don Quijote del patriotismo social que vive estudiando Brasil, pero sólo a través de libros, durante 30 años en todos sus aspectos, regiones, épocas, riquezas naturales y culturales, para poder sugerir reformas a fin de mejorar la vida de los brasileños, primero en el área cultural, después en la agricultura, y finalmente en la política. Una actitud loable, pero que en ese caso concreto oscila entre generosa y ridícula, debido a la falta de conocimiento empírico de la realidad, falta de viajes, falta de espíritu crítico. Y hay una elite que sabotea cualquier reforma iniciada para el bien de la población.

RA: Parece que usted como estudioso de Brasil se identifica bastante con personajes que hacen precisamente lo mismo: investigar el Brasil.

BZ: Bien, identificarme, no sé, pero claro que me quedo admirado o sensibilizado, u otras veces indignado con situaciones o personajes, pienso en ellos, y pienso en situaciones parecidas de las que tengo conocimiento, o en las que yo mismo estuve podría estar un día. Claro que uno tiene la relación también emocional o sentimental no sólo con textos, sino también con algunos personajes; me sentí cercano a Euclides investigando la verdad sobre la guerra de Canudos, y creo que uno puede incluso impresionarse con personajes lejanos a uno, como Paulo Honorio, en San Bernardo, el caboclo que llega a ser hacendado rico pero que destruye su propia felicidad debido a su codicia, desconfianza, brutalidad. Puede haber algo como empatía sin identificación, creo. Pero es verdad, me siento cercano al tipo del investigador patriótico, abnegado, que intenta conocer a fondo su país para ayudarlo a ser más justo, desarrollado, civilizado. Hay, en la realidad y en la ficción, pensadores que investigan el Brasil para hacer lo mejor; son patriotas íntegros, cultos e idealistas, no xenófobos, como por ejemplo Alexandre Rodrigues Ferreira, aunque este fuera portugués, Gonçalves Dias, Taunay, Couto de Magalhães, Euclides, Candido Rondon, Carlos Chagas, Mário de Andrade, Antonio Callado, Darcy Ribeiro y muchos otros. Y a veces viajeros extranjeros también desempeñan ese papel, como Langsdorff, Martius, Hercule Florence, Rugendas, Ferdinand Denis y muchos otros. Personas que quieren, sin mucha ambición egocéntrica, poner en práctica sus conocimientos y valores humanistas, 
queriendo ser útiles también en términos prácticos. Como Policarpo Quaresma, que decía trabajar "para la grandeza y la emancipación de la Patria". Después él cuestiona el patriotismo oficial, con razón. Emancipación aquí significa, también, liberación e inclusión de los estamentos subalternos, ciudadanía y dignidad para todos; eso me toca, sí. ¿De qué sirven conocimientos y teorías si no mejoran el mundo? La decisión de Policarpo de aplicar su saber en la práctica llegar a recordar un famoso aforismo de Carlos Marx, la 11 a tesis sobre Feuerbach: „Die Philosophen haben die Welt nur verschieden interpretiert, es kömmt darauf an, sie zu verändern“: "Los filósofos sólo han interpretado el mundo de modos diferentes; lo que importa es transformarlo." ¿Me permite una observación sobre la traducción de esa frase? Esta que improvisé, como todas las que conozco, tiene un problema, no semántico, sino estilístico, un buen ejemplo de la importancia de la forma, de la sintaxis, del ritmo, y de la reflexión productiva, incluso en textos no literarios. La frase en alemán es un paralelismo de dos oraciones que terminan, ambas, con un verbo, oponiendo estructuralmente el "interpretar" y el "transformar". Como en portugués es difícil poner el verbo después del complemento directo - sólo Guimarães Rosa lo hace de vez en cuando- la traducción no logra reconfigurar esA estructura. Así, a veces uno se encuentra con los límites de la traducibilidad, principalmente en los planos sintáctico y sonoro. A propósito, Marx era un maestro de la lengua alemana.

RA: ¿Piensa usted que Brasil tiene una atracción especial para los extranjeros? ¿Po rqué?

BZ: Brasil ejerce una atracción muy especial hace siglos, no sé por qué; desde los tiempos del descubrimiento encantó a muchos extranjeros: Pero Vaz de Caminha, Vespuci, Staden, Jean de Léry, Maurício de Nasau y su equipo, el pintor Eckhout, por ejemplo, después los integrantes de las misiones extranjeras en la época de Don João VI y su nuera doña Leopoldina, Taunay, Wied, Florence, también más tarde legiones de naturlistas, pintores y etnólogos, como Koch-Grünberg, que registró las leyendas en torno de la figura de Macunaíma, fuente de inspiración para Mário de Andrade. Esa fascinación tiene que ver con los muchos descubrimientos científicos y antropológicos que se podía hacer aquí, pues Brasil era una tierra inmensa incógnita ignota, pero no sólo eso. Incluso gente que nunca estuvo en Brasil, —como Montaigne, Humboldt, Goethe, Döblin — quedó fascinada con este país, escribió sobre él. Goethe lamentó que, al conocer Brasil a través de las lecturas y también conversaciones con Eschwege y Martius ya tuviera más de 60 años, sin condiciones de viajar personalmente para aquí. Hace unos 10 años, un historiador alemán, Syle Schneider, compiló y comentó todo lo que escribió y habló sobre Brasil: ¡eso dio un libro de 200 páginas! ¿Por qué tantos alemanes consideran a Brasil un Sehnsuchtsland, país de añoranza? Quizás un poco por la extensión casi infinita, riqueza y belleza del territorio, por la diversidad asombrosa de los paisajes, de las poblaciones, de las expresiones culturales, la hospitalidad de la población, el enorme potencial de desarrollo del país, que así se presta servir con la como pantalla de proyecciones, como tierra prometida, visiones edénicas, sobre las cuales Sérgio Buarque de Holanda escribió un importante libro con enfoque en la época de los descubrimientos, pero son visiones que sobrevivieron, no sólo en Stefan Zweig. Se mezclan con visiones pesimistas o incluso terroríficas e infernales, y en la literatura más moderna estas últimas parecen incluso prevalecer, con mucha crítica social, mucho retrato de la violencia, injusticia social y jurídica, de la corrupción; pero la esperanza por último la esperanza es la última que muere, realmente, para que no vive en la 
miseria, Brasil puede ser una tierra muy atractiva. No conozco ningún extranjero que después de algún contacto más profundo con Brasil no se haya pegado este país. Todos parecen seguir problema: einmal Brasilien - immer Brasilien: una vez Brasil — Brasil para siempre.

RA: ¿Y dónde viene su fascinación con el sertón?

BZ: Como he dicho, siempre me sentí bastante atraído por el sertón, su paisaje, su historia, su imaginario, su música, Luis Gonzaga, los movimientos sociales religiosos, los cangaceros, sus contradicciones sociales, las uniones campesinas... puede ser que haya hay algún romanticismo o exotismo, un cierto gusto por una realidad diferente, incluso opuesta al mundo vivido y a la civilización urbana que uno conoce, un cierto aventurerismo mental. Más tarde, en los años 70, cuando pasé dos años como profesor visitante en fortaleza, leí Os sertões, o lo intenté leer, impresionándome con sus paneles grandiosos, las escenas dramáticas y trágicas de la guerra, el martirio del hombre y de la naturaleza, los aspectos infernales y heroicos de los dos, la injusticia y la lucha por la justicia, aprendí lo que es la religiosidad popular, el coronelismo, la sequía como fenómeno no sólo físico sino también antropogénico el problema del colonialismo interno, cuando el gobierno trata el sertón como si fuera un territorio extranjero, ocupado por Brasil, un fenómeno que más tarde también conocí en Argentina.

Os sertões, discutiendo la historia y los problemas de una región carenciada, discute problemas de la nación, y aun de la humanidad. No es por casualidad que este ensayo poético-científico-histórico, como otras obras -libros, obras teatrales, películas- que nacieron de la observación y de la reflexión sobre interior pobre, seco y atrasado, se consideran importantes interpretaciones de sus países, trascendiendo lo regional y lo estrictamente literario y artístico, y constituyendo "lugares de memoria, "en el sentido de Pierre Nora. No sólo Os sertões, sino también Facundo, de Sarmiento, Radiografía de la pampa, de Martínez Estrada, El llano en llamas, de Rulfo, Los de abajo, de Azuela, siendo incluso obras fundantes, en el sentido de Doris Sommer. Tienen como escenario de su trama, como objeto de reflexiones y casi como protagonista, regiones poco desarrolladas, violentas, "bárbaras", maltratadas por las elites, y quizás por eso mismo inquietas y a veces rebeldes. Así el Estado moderno está ausente o muy reducido, se trata de regiones de "estatalidad limitada", limited statehood, como dicen los politólogos, como si pertenecieran a un Estado fundido, failed state. Territorios que cada dos por tres chaman la atención, cuando la permanente violencia se transforma en guerra civil, y cuando ocurre una emigración masiva, como aún hoy ocurre en muchas partes del mundo. Quien manda allí no son el Estado, el municipio, la sociedad civil, sino los coroneles, caciques, caudillos, precursores de los warlords de países del África y del Asia de hoy, aliados o enemigos del gobierno central o de la oposición, cuando esta existe. Esto había en la pampa, en los llanos, en los sertones, en las selvas, en el altiplano hasta hace pocas décadas atrás, y la literaturas latinoamericanas hablan de ello. Y eso aún existe en espacios suburbanos, en las favelas, verdaderas no-go-areas, miniestados dentro del Estado, donde las autoridades constituidas casi no tienen autoridad, como antiguamente en el sertón; basta leer Cidade de Deus, de Paulo Lins.

Se trata de regiones y sociedades menos complejas, en las cuales, sin embargo, se plantean cuestiones existenciales, de modos específicos e históricamente marcados, pero que en sus estructuras profundas son universales. De ese modo, para el observador 
y para el lector, funcionan como laboratorios sociológicos y psicológicos de la condición humana: ¿cómo se puede organizar la satisfacción de las necesidades básicas, a nivel individual, municipal, nacional? ¿Cómo proveer comida, vivienda, salud, educación, el metabolismo con la naturaleza, que es enemiga y amiga al mismo tiempo, cómo construir la convivencia civilizada, en el plano privado y el político, organizar el trabajo, la administración, la política, cómo lidiar con el poder y el abuso de poder, justicia e injusticia, cooperación y explotación, anhelo de libertad, ciudadanía, guerra y paz también: cómo encarar la lucha entre el bien y el mal, dialécticamente entrelazados, y tan difíciles, a veces, de definir?

Esos paisajes del interior, física y económicamente carenciados, pueden ser ricos cultural y metafísicamente. No será por casualidad que algunas religiones del mundo, el judaísmo, el cristianismo, el islamismo, hayan nacido en regiones marginadas, pobres, secas, casi desérticas, del Cercano Oriente, regiones asociadas por muchos autores latinoamericanos al sertón, a la pampa y el llano. El sertón incentiva al viajero a la meditación, por ser poco habitado, poco cómodo, tener un horizonte amplio y bonito, un cielo majestuoso y sugestivo, a veces con nubes enormes, pero poca lluvia, con matices cambiantes de luz de acuerdo con las horas del día y la estación del año. También tiene un pueblo acogedor, llano, perseverante, que sabe contar muchas historias, reales y fantásticas, un pueblo que no se resigna, que lucha, que se vuelve a levantar. Espero no estar idealizando demasiado mi querido sertón.

RA: ¿Por qué, más específicamente, le fascinó tanto Os sertões?

BZ: Canudos fue una de las pocas ocasiones en que el pueblo explotado o abandonado, y siempre despreciado por las élites, por los poderes constituidos, por los letrados, prensa, iglesia, por todo el mundo, ese pueblo tomó su destino en sus propias manos, dejando de ser solamente objeto, haciéndose por un brevísimo período sujeto de su historia. Me conmueve ver la empatía y el entusiasmo de Euclides, verlo superar, por lo menos parcialmente, sus propios prejuicios racistas y antipopulares, ver cómo retrata y admira a los olvidados de la historia de las letras que se reúnen y se organizan para fundar una comunidad, casi una ciudad, en un semidesierto. Esa comunidad no es precisamente democrática, pero sí mucho más igualitaria y mucho más basada en el consenso y en la participación de todos que la situación de los vaqueros y labradores en las haciendas y en las ciudades, dominados por las estructuras coronelistas. Eso explicó el gran flujo de sertaneros hacia allá, lo que irritaba a los latifundistas de la región. Y esa "Troya de tapia" sin ayuda de fuera, sin ayuda de nadie, es capaz de satisfacer las necesidades básicas de 10000 o 15000 personas. Condenando la destrucción de esa comunidad, Euclides también se acusa a sí mismo, pues él mismo participó en esa campaña de exterminio, aunque no como combatiente directo. Tiene toda la razón cuando chama tragedia al hecho, pues los dos partidos, por lo menos subjetivamente, defendían nobles principios y propósitos, una vida de acuerdo con la fe de Dios versus la nación, la República y la Civilización —condición, según Hegel, para una colisión trágica- Sin embargo, allí la civilización se volvió contra sí misma haciéndose bárbara, incluso por no dialogar con los supuestos bárbaros. Quiso imponer el progreso autoritariamente, como hizo en la campaña contra la viruela, que provocó la Revolta da Vacina [Revuelta de la Vacuna] en Rio de Janeiro, en 1904. Con su libro, Euclides problematiza también el papel del intelectual ante las injusticias sociales y las reivindicaciones de víctimas de la injusticia, que él, por otro lado, no idealiza. Y Euclides tuvo un insight que varios grandes escritores y pensadores también tuvieron, 
como Rousseau, Diderot, Goethe, en su Fausto, y que Horkheimer y Adorno formularon filosóficamente como la Dialéctica de la Ilustración. Esta es también la dialéctica de la Civilización, de la Modernidad, aún de la democracia que promete el progreso tecnológico, administrativo y científico, un mayor dominio de la naturaleza, la sustitución del mito por el saber, un mayor bienestar, menos sufrimiento, pero que en el plano de la realidad social y ética produce a veces lo contrario, promueve guerras, desigualdad social, trabajo esclavo, marginación o destrucción de poblaciones tradicionales sin ofrecerles las condiciones alternativos de supervivencia digna, creando nuevos mitos, autoritarismos incluso fanatismos. Es eso lo que Euclides quiere decir, entre otras cosas, cuando chama la rua do Ouvidor "atajo a las sendas del Sertón".

RA: ¿Fueron esas temáticas, esos conflictos, esos paisajes lo que le inspiraron a traducir Os sertões?

BZ: Sí, quise entender Os sertões, tuve problemas, busqué una traducción, no la encontré, entonces decidí hacerla yo mismo, y, de cierto modo, así me hice traductor: Euclides me hizo traductor. Considero el traducir como una crítica literaria aplicada, o incluso, como dicen los alemanes que hacen de todo una ciencia: una ciencia de la literatura aplicada, es decir, traducción como continuación de los estudios filológicoliterarios por otros medios. En el fondo, no soy traductor profesional, cuando mucho soy un traductor esporádico. Pero ya estaba cerca de ser traductor, pues el trabajo del crítico literario en gran parte es igual al del traductor: disecar el texto, investigar su estructura, los elementos y la relación entre ellos, entender cómo funciona esa estructura, cómo vive, en el diálogo con el lector, y en el contexto histórico social, dentro de la vida literaria de un modo general. Es decir, existe una etapa más bien analítica y una etapa más bien interpretativa de la tarea del crítico, que puede entrar, más o menos profundamente, en las esferas de la psicología, antropología, sociología.

Todo traductor, por lo tanto, también es crítico, por lo menos un crítico implícito, pero va más allá: no sólo estudia la anatomía del texto, su fisiología, su vida en el contexto cultural, social, político, lo que también hace el buen crítico, principalmente el que lleva a cabo una close reading o una explication de texte. Pero además de eso, el traductor aprovecha el análisis, la identificación de las principales propiedades y significados del texto fuente, para producir un nuevo texto literario, en otra lengua, en el que se preserven de forma metamorfoseada esas propiedades, la sintaxis, el vocabulario, el ritmo, las metáforas, figuras sonoras, las alusiones intertextuales, el efecto intelectual y emocional en el lector, en la medida de lo posible. El traductor da un soplo de nueva vida al texto, lo hace revivir en otras latitudes, en otra cultura, quizás otra época. Lo ideal sería que la traducción produjera efectos semejantes en el los nuevos lectores, ideas, imágenes, emociones parecidas a las que tuvo el lector del original, pero en diálogo con la cultura de llegada. Intenté hacer eso con Os sertões, un ensayo polivalente que tiene algo de un romance, de un drama, de un poema, de un "Génesis" del Brasil, de un panfleto político, de un discurso fúnebre. Quería rescatar no sólo el aspecto científico del texto, los términos geológicos, botánicos, filosóficos, usados a veces metafóricamente, sino también la cualidad retórica del libro, que imagino como un manuscrito de un gran discurso que Euclides, en un amplio anfiteatro, dirige a la nación brasileña, a sus gobernantes y letrados, para informarlos, reprenderlos, pedirles por el sertón y los sertaneros, por un Brasil más justo y más pacífico. Intenté recrear el ritmo y el ímpetu de esa oralidad erudita, repleta de alusiones mitológicas, bíblicas, positivistas, pero también de sabidurías de los mismos 
caboclos. Creo en el ideal de una estética de la exactitud, en el análisis y en la recreación, sabiendo que se trata, en rigor, de un ideal inalcanzable, pero uno lo intenta.

RA: ¿Le parece usted que la literatura brasileña tiene un mayor compromiso con la realidad que la europea?

BZ: En clases y en tratados de teoría literaria se enseña que, en literatura, lo que importa no es el qué, sino el cómo. Es verdad, la literatura es el arte de la palabra, el arte de configurar palabras y sus conexiones, al nivel de la colocación, del sintagma, de la frase, del período, del párrafo, del capítulo, y de todo el texto. Estudiamos textos en su configuración lingüística, estética, temática, emocional y así en adelante. Y como traductor, tengo que concentrarme primero en el lenguaje y su organización, al paso que la composición de la trama de los caracteres me preocupa solo en la medida en que siempre aparece configurada lingüísticamente. A primera vista, sólo tenemos la superficie lingüística, el resto es trabajo del lector, interpretación. Lo que distingue el lenguaje literario del lenguaje cotidiano o técnico, también del lenguaje científico, es justamente la forma, la hechura estética, función poética, como dice Jakobson, la preponderancia de esta con respecto a las otras funciones de un texto, la referencial, la expresiva y la apelativa, sobre todo. Pero esto no quiere decir que el qué no importe. Imaginemos Os sertões de Euclides da Cunha tal cual conocemos el texto, pero con una diferencia, una hipótesis: sería pura ficción, nunca habría ocurrido la guerra de Canudos, sería todo una pura novela, que se referiría quizás vagamente a guerras religiosas y guerras civiles en alguna parte del mundo, pero no habría un lugar con el nombre o las características de Canudos ni guerra en el sertón de Bahía. ¿Cómo leeríamos el libro? Ninguna palabra se cambiaría, pero Antonio Conselheiro, el general Arthur Oscar, Pajeú, la Iglesia Nueva, el rio Vaza-Barris, el degüello de prisioneros solo existirían como entidades ficticias, no como pasado real, extraliterario. Ciertamente leeríamos el libro de otra manera, con menos emoción, con menos beneficio intelectual, pensaríamos menos: tua res agitur, que se trataría de un asunto tuyo, mío, nuestro, aprenderíamos menos sobre el Brasil, sobre el sertón, sobre "las locuras y los crímenes de las nacionalidades", como dice Euclides al final. Si ese libro no me ayudara a comprender mejor la realidad yo no lo habría traducido.

La relación del texto con el mundo real es fundamental para la recepción e interpretación de una obra. Aunque, como sabemos, el acceso a la realidad extratextual no es directo, sino a través de la memoria de las personas y colectividades, a través de textos escritos, imágenes, objetos, y que nunca puede ser reconstruida en su integridad - principalmente cuando se trata de épocas remotas-, eso no invalida la importancia del hecho, por más difícil que sea definirlo en su totalidad. Así, una buena dosis de positivismo, aunque salpicada de dudas epistemológicas y constructivistas, es útil y necesaria. Euclides decía de sí mismo que, para escribir, era como ciertos pájaros: para alzar el vuelo necesitaba una rama, y esta rama era el hecho.

Por otro lado: ¿por qué no escribió un relato puramente factual y objetivo, puramente periodístico o científico, militar, técnico, antropológico, etc.? Porque él sabía que el sólo relatar hechos no es merecedor de los hechos ni de los lectores. Era necesaria la imaginación para dar vida al relato de los hechos, insertarlos en la trama de una narrativa, aquello que el historiador norteamericano Hayden White chama emplotment, para plasmar los acontecimientos en paneles y escenas imponentes e impactantes. Para ello, él debía conocer la mentalidad de los personajes relatados, la poesía y la religiosidad del pueblo, hacer una especie de antropología poética, no sólo 
para hacer el relato más accesible al público leedor/lector [¿qué es mejor?], sino para entender mejor la realidad ocurrida, su estructura, su desdoblamiento, sus imaginarios colectivos, sus aspectos subjetivos. Él quería entender la guerra en su totalidad, entender a los sertaneros y a los soldados, entender la civilización asesina, tenía por así decir una casi fanática voluntad hermenéutica. Esta no iría lejos sin el "consorcio de la ciencia y del arte", como Euclides llamó su poetización de la historia de la ciencia.

Para Hegel, el arte no solo permite, sino que debe revelar la verdad, y eso de una manera plástica, como "das sinnliche Erscheinen der Idee", la "aparición sensorial de la idea", más o menos así. Si Euclides quiso conmovernos en favor del pueblo menospreciado del interior, a través de un retrato de guerra, causas, condiciones, características, consecuencias, si el llamaba a Os sertões "libro vengador", ¿eso sería un abuso de la literatura? Apelar a la solidaridad con los vencidos y víctimas de injusticias, ¿no sería una de las funciones genuinas de la literatura? Creo que no es sólo Euclides quien vio esa responsabilidad de las artes por la construcción de un imaginario verdadero y al mismo tiempo crítico y utópico, con relación a las realidades en las Américas y en el mundo. Ese compromiso existe desde la independencia, desde José Bonifacio, Macedo, Manuel Antonio de Almeida, Castro Alves, Machado, Pompeia, Graciliano y centenas de otros autores. Incluso porque, hasta el siglo XX, había poca división del trabajo intelectual en el nuevo mundo de modo que los artistas literatos se encontraban en la necesidad de asumir funciones de geógrafos, antropólogos, historiadores, psicólogos y así en más. Los poetas y escritores fueron pioneros en la descripción del día a día del pueblo, de su mundo vivido, su mentalidad, de las costumbres y relaciones sociales, en las ciudades, en el sertón, en la selva.

RA: Actualmente usted está trabajando en una nueva traducción de Grande Sertão: Veredas al alemán. ¿Cuáles son los desafíos, también en comparación a Os sertões? ¿Qué facilidades y dificultades conlleva una segunda traducción de un texto?

BZ: Sí, actualmente estoy trabajando en la travesía traductora del Grande Sertão y sus muchas Veredas, y entiendo el premio Blaise Cendrars también como un incentivo para llevar a cabo esta tarea del traductor con nueva energía, coraje y viento en popa, pero sin pacto diabólico, incluso porque Riobaldo constató que "o diabo não há" [el diablo no hay].

Por primera vez estoy traduciendo un texto que ya ha sido traducido al alemán, es decir, se trata de una retraducción, una nueva traducción a un mismo idioma. Además, ese libro se ha sido traducido a otras lenguas que conozco, siendo esas traducciones objeto de muchas investigaciones, también de las mías. Pues bien, esas traducciones anteriores y los estudios sobre ellos forman parte, junto con la crítica literaria académica y periodística, de la fortuna crítica y de la historia de recepción. Y sabemos que, queriéndolo o no, la lectura y, por lo tanto, también una traducción de un texto, no puede abstraer totalmente su recepción; por el contrario, pues esta forma parte del imaginario de aquel texto. En comparación con otros abordajes críticos - la reseña periodística, el análisis académico, sea lingüístico, poetológico, sociológico, filosófico... que se vuelcan hacia determinados aspectos - la traducción analiza una obra en su integridad, elaborando un implícito metalenguaje, convertido en obra literaria paralela, un comentario continuo. Haroldo de Campos, hermenéuticamente, chama a la traducción una forma privilegiada de lectura, pues penetra en los "mecanismos y engranajes más íntimos" del texto, revelando sus "operaciones formadoras". El autor de una retraducción se ve, por lo tanto, ante una enorme 
oportunidad, pero también ante la dificultad de tomar en cuenta, de algún modo, la fortuna crítica del original, a la cual pertenece su fortuna traductora, que a su vez formó la idea que muchos lectores tienen del original. Las traducciones anteriores son útiles, pero también dan trabajo y consumen tiempo. Son instructivas sobre todo traducciones a la propia lengua del "retraductor", y a lenguas cercanas, que en el caso del alemán es el holandés, y ahí tenemos la buena traducción de Willemsen.

Las tareas del traductor son muy distintos en Os sertões y en Grande sertão: veredas, pese al parentesco entre los dos libros, no sólo en los títulos, sino en el contexto geográfico, social, cultural, también el vocabulario, y en el enfrentamiento entre civilización y barbarie, aunque éste aparezca de modo más indirecto en Guimarães Rosa. No sólo los géneros literarios indistintos, sino sobre todas las estructuras narrativas y los estilos, pues a la vez que Euclides hace música sinfónica, para un gran público, Guimarães Rosa hace música de cámara, para un solo oyente, que por otro lado representa la totalidad de los posibles lectores. El narrador roseano no tiene un manuscrito pronto, sino que formula sus ideas y recuerdos ad hoc, en un diálogo. Es decir, la suya es, o finge ser, una oralidad más espontánea, coloquial, íntima, más regional, más sertanera y brasileña, con más elipsis y más elementos y idiolectales que en Euclides, con un mayor grado de hermetismo. Y Euclides se dirige a un público internacional de forma más directa que Rosa. Los procedimientos poéticos de este último no siguen las reglas de los manuales poéticos y retóricos, las reglas de ese lenguaje, su morfosintaxis: son una invención de Riobaldo y de su autor. De ahí se desprende que la erudición y la investigación sean más complicadas que en el caso de Euclides. Para entender Os sertões es útil estudiar la retórica y la historiografía clásica, a Heródoto, Tucídides, Cicerón, Quintiliano; pero para estudiar a Rosa eso rinde menos, pues Guimarães Rosa tiene un lenguaje muy insólito, singular, muy lejano a otros autores, clásicos o modernos, brasileños o no, aunque los haya leído, visiblemente, incluso a Homero, Platón, Dante, Nietzsche, Joyce. Es necesario estudiar los procedimientos y principios de él, incluso leer sus autocaracterizaciones para retirar de allí enseñanzas y sugerencias sobre la estrategia de traducción de Grande sertão: veredas.

RA: ¿Entonces le parece que el mismo del texto fuente surgen algunas sugerencias sobre el modo en que debe ser traducido?

BZ: Exactamente. El método de la traducción resulta de cierta manera del método de producción del texto que uno desea traducir — naturalmente con la condición de que el público de la cultura meta sea comparable al de la cultura fuente-. Si un texto hecho para un lector que conoce a Homero, Shakespeare, Joyce se traduce para un público, digamos, infantil o juvenil, las cosas son distintas, claro. Pero en el caso de Guimarães Rosa, generalmente el público internacional tiene algunas afinidades, aunque ya haya también adaptaciones de Grande sertão: veredas, incluso como graphic novel. Si la crítica de un texto, la reconstrucción mental de sus propiedades estéticas, forma parte de la tarea del traductor, si la traducción es crítica y creación, como dice Haroldo de Campos, y si todo texto de alta calidad estética y, por decir así, antropológica, tiene un alcance que trasciende los límites de la comunidad cultural y lingüística para la que fue escrito, entonces se puede decir, con Benjamin, Haroldo, Berman, y el mismo Guimarães Rosa, que un análisis textual minucioso y empático nos da indicios de la estrategia de una traducción apropiada para ese texto. Bejamin dice que los grandes textos contienen en las entrelíneas su traducción virtual, yo creo en ello. 
Claro que no hay sólo una única traducción virtual, puede haber varias, pero no cualquier traducción es adecuada, capaz de dejar transparentar las cualidades del original, como un palimpsesto. Rastreando minuciosamente el camino que el autor recorrió al escribir, el traductor puede volver a andar ese camino en otro idioma, de forma aproximada. La traducibilidad, y un cierto margen de maniobra en la traducción, está incorporada en el original, que nos da pautas, avisos, recomendaciones sobre el modo en que él puede o "quiere" ser leído por extranjeros, y su lectura es un primer paso para la traducción. Un texto no sólo tiene su "lector implícito", como dice Wolfgang Iser, pero, según lo veo, tiene también su "traductor implícito", anticipando y pidiendo su reconfiguración en otro idioma. El potencial interpretativo y expresivo de ese idioma meta debe ser aprovechado, con la mayor flexibilidad posible, para adecuarse y asimilarse al texto y a la lengua de partida y expresar sus principales cualidades semántico-estéticas. Algunas características del texto resultan realzadas, otras quedan en segundo plano, es un juego de pérdidas y ganancias.

RA: Se conocen las cartas que Guimarães Rosa intercambiaba con sus traductores. ¿Qué podemos aprender del diálogo de ellos con relación a la traducción?

BZ: Justamente, Guimarães Rosa, además de un gran escritor fue un poeta doctus, y alguien que tenía ideas muy claras sobre estrategias traductivas. Además de eso, él mismo tenía experiencia como traductor; tradujo, aún como estudiante de medicina, textos científicos, y más tarde incluso una novela de un escritor canadiense, Fred Bodsworth, Last of the Curlews, $O$ último dos maçaricos [publicado en español como El último chorlito, en traducción de Alberto Gutiérrez Castro. En Biblioteca de Selecciones, v. 2, La Habana, Madrid, Nueva York, 1958], cuyos personajes son aves, una transcreación muy cuidadosa, en que uno puede apreciar no sólo la reconfiguración poética, sino también la investigación ornitológica que hizo Guimarães Rosa. Entonces él sabía muy bien lo que la traducción. Y tenía una clara idea de lo que yo llamo traductor implícito que él quería explicitar para sus traductores reales. Rechazaba "expresiones domesticadas y acostumbradas", quería "chocar y extrañar" al lector, odiaba tópicos y clichés, frases hechas, y prefería un estilo paratáctico para dar autonomía a las partes del habla. Quería que cada palabra, cada sintagma, cada oración repercutiera de una forma especial, sugestivo, llamando la atención hacia así hacia la trama y los personajes, hacia el sertón y hacia el mundo, contra jerarquías sintácticas lógicas. Quería ser opaco, misterioso, sugestivo, a través de palabras y colocaciones inusitadas, elipsis sintácticas y lógicas, cierta abstracción en la figuración de acontecimientos, personajes, paisajes y objetos, para aumentar la alusividad. El lector debía tener mucha libertad para rellenar los "blancos" del texto con su imaginación. Él establecía una colaboración entre autor y traductor, ya que quería que los traductores asumieran los mismos principios y procedimientos estéticos que profesaba, pues él no distinguía nítidamente, al nivel de la confección lingüística, entre el crear y el recrear.

Las ideas estéticas y traductivas del mismo autor tienen mucho en común con concepciones de de la hermenéutica y de los Estudios de Traducción, de Schleiermacher, Berman, Benjamin, Venuti, dando preferencia — contra prácticas asimiladoras, etnocéntricas, domesticadoras- a estrategias extrañadoras, reconfiguradoras, extranjerizantes. Pero por otro lado él sabía que rescatar completa y perfectamente en otro idioma la "manera de decir" - expresión del mismo Guimarães Rosa- del original era difícil o incluso imposible, principalmente en los años 60 del 
siglo XX. Entonces terminó aceptando y aún elogiando traducciones que en el fondo contradecían sus propios principios poéticos.

RA: ¿Cuál es su opinión sobre la primera traducción de Grande sertão: veredas al alemán? ¿En que pretende distinguirse de ella, en la meta y en la estrategia?

BZ: Es un poco delicado hablar sobre la obra de un gran antecesor, amigo de Guimarães Rosa, muy elogiado por él, un importante embajador, por decirlo así, de la literatura brasileña y de literaturas ibero-románicas en la cultura de lengua alemana. Por otro lado, traducir al alemán como lo hacia él, hoy en día, es algo que no hace nadie, a partir de ninguna lengua, cuando se trata de literatura de alto nivel estético. Los estándares traductivos han mudado bastante. Meyer-Clason fue un representante de una época en que, en la práctica literaria, poco se distinguía traducción de adaptación y paráfrasis, siendo el traductor señor casi absoluto del texto meta. Tenía que obedecer sólo a las orientaciones de los editores, a la expectativa del público, a su propio gusto estético, no había crítica de traducción, no había "abogados" del original exigiendo que se le fuera leal. Meyer-Clason transpuso el portugués roseano, extremadamente distante del portugués estándar, a un alemán fluido, corriente, bonito, pleno de colores, de imágenes, sonoro, sin cualidad diferencial alguna con respecto al alemán estándar, cumpliendo enteramente las expectativas del público con relación a autores de ficción latinoamericanos, incumpliendo casi totalmente los principios poéticos de Guimarães Rosa. Un estilo que podría ser el de García Márquez, de Jorge Amado, de Adonias Filho y de muchos otros autores vertidos por el mismo traductor. Así, el lector no pudo conocer el habla pausada, a tientas, espontánea de Riobaldo, de su coloquialismo de hacendado meditabundo, que fue matón, un lenguaje lleno de infracciones contra la norma culta y la lógica discursiva, lleno de elipsis, anacolutos y laconismos, aquella oralidad al mismo tiempo popular y sofisticada, regional y filosófica, siempre absolutamente nueva y poética. Esa traducción alemana justamente hace lo contrario a todo lo que Guimarães Rosa quería, no choca, no resulta extraña, no es opaca ni enigmática, no es metafísica, completa elipsis gramaticales y lógicas, usa y abusa de lugares comunes y proverbios conocidísimos. Por otra parte, practica numerosas veces una jerga urbana a veces incluso vulgar, que recuerda novelas populares sobre la Segunda Guerra Mundial, un registro totalmente ajeno al portugués de Riobaldo. Pues este, pese a su poca escolaridad, evita cualquier vulgaridad, teniendo incluso una notable delicadeza en los registros que usa, que oscilan entre el coloquialismo cotidiana y lo sublime. Más grave en el procedimiento del traductor quizás sea la tendencia ilustrativa, ornamental y amplificadora al relatar situaciones y acciones, pues el traductor parece querer corregir un cierto abstraccionismo del autor, un casi ascetismo en la pintura de la realidad, inventando detalles de la trama y los personajes que no aparecen en el original.

Unos ejemplos. Bien al principio aparece un becerro deforme que los hombres de Riobaldo matan, lo que se expresa de una manera lacónica: "Mataram" [lo mataron]. Eso se transforma en alemán, aquí traducido: "ellos lo mataron a golpes inmediatamente", es decir, el autor agrega un adverbio y concretiza el modo de matar, "corrigiendo" el relato relativamente sobrio y abstracto del auto. Cuando el Riobaldo brasileño dice "O acampamento da gente parecia uma cidade" [nuestro campamento parecía una ciudad], su tocayo alemán dice, traducido: "El campamento zumbaba como una colmena", lo que en alemán es una imagen bastante usual, un lugar común, bonito, pero no es Guimarães Rosa. "Eu tinha o medo imediato" [yo tenía el miedo inmediato] 
se transforma en "Yo tenía miedo desde las raíces del pelo hasta las puntas del pie". La muerte del marido de María Mutema se narra en el original con poca concreción, pero con una redundancia, además una cuádruple aliteración: "morreu, amanheceu morto de madrugada", lo que parece casi un oxímoron o paradoja, como si dijera: "se despertó muerto". El traductor alemán ignora la redundancia y por otro lado comete una amplificación, inventando una información adicional: "de mañana él estaba acostado muerto en la cama". Claro que probablemente aquel hombre solía dormir en una cama, aunque hubiera también la alternativa de la hamaca. De cualquier modo, si el autor prefiere silenciar aquí el lugar exacto del sueño y de la muerte del personaje, retratando la realidad con escasas y sugestivas pinceladas, el traductor no debería agregar detalles concretos, visibles, palpables, dando a su representación de la realidad un carácter más práctico, más ilustrativo, más realista —y más tradicional—. Al principio de la primer del primer cruce del Liso do Sussuarão, Riobaldo resumen con concisión genial el shock que le proporciona ese desierto: "Vi a Luz, castigo" [vi la luz, castigo]. En alemán, eso aparece de forma barroca: "Yo solo vi luz, dolorosa, y fue como un castigo". En un texto poético, la secuencia de los sintagmas, de las ideas e imágenes forman parte de la configuración estética, aspecto que el traductor alemán ignora mucho más allá de las imposiciones gramaticales de la lengua alemana. Las permanentes infracciones del traductor contra la poética condensadora, elíptica, alusiva de Guimarães Rosa tiene una contrapartida en el aplanamiento de aparentes redundancias, como por ejemplo en la recurrente expresión roseana "homem humano" [hombre humano], qué pierde su adjetivo en la versión alemana. ¿Quién le permitió hacer eso al traductor? "homem humano" es mucho sugestivo, pues el lector justamente se pregunta que podría significar esa duplicación léxica y semántica, una figura etimológica. ¿Cómo puede un traductor eliminar ese y otros recursos estilísticos? Esto ocurre miles de veces en la traducción, imagínese. Otro problema es la tendencia a ignorar isotopias, palabras clave que reaparecen en determinados fragmentos del libro, guiando la lectura y estructurando la masa de texto. Una de ellas es "veredas" [senderos], que en el texto alemán se traduce por media docena de términos muy distintos, de modo que el lector no tiene la oportunidad de notar el papel estructural y poético de este término, concreto y simbólico, que aparece desde el título, es decir que las veredas pierden su identidad. Balance: la primera traducción alemana es muy buena en el sentido de seguir el modelo tradicional de las "belles infidèles". Pero eso significa que, contrariando la poética roseana, adapta el texto al supuesto paladar de los lectores alemanes de la época, sin darles la oportunidad de formarse una idea de la hechura estética del original.

RA: Observando la tradición de traducciones de Grande sertão: veredas, ¿se puede decir que hay una evolución en las estrategias de traducción? ¿Es posible que una traducción con profusión de palabras y construcciones extrañas cuente con la aceptación del público alemán?

BZ: Quizás haya sido inevitable familiarizar, cuatro décadas atrás, al público alemán con la obra innovadora y singular de Guimarães Rosa disminuyendo drásticamente esa novedad y singularidad. Pero ahora, me parece, el texto roseano merece ser "transcreado", como diría Haroldo de Campos, sin censura, sin eliminación ni añadido de ningún elemento expresivo, emotivo o ideológico —en la medida de lo posible, claro-, para permitir al lector de lengua alemana rastrear, conocer, vivir algo de la polisemia, fuerza sugestiva, mezcla de oralidad popular, erudición filosófica y experimentalismo estético del original, algo del riquísimo potencial de significados que 
está disposición del lector del original, añadido de significados sugeridos por la cultura y por la fantasía del lector de la cultura de llegada. Pues en el caso de textos poéticos es importante que traduzcamos no sólo lo designado, sino el modo de designar las cosas, como dice Benjamin. Se puede vislumbrar, en el curso de más de medio siglo de esfuerzo traductivo dirigido a Grande Sertón: veredas, una tendencia a un respeto cada vez mayor por la poética roseana, gracias a mayores facilidades de investigación, y sobre todo gracias a una mayor disposición, de parte de los lectores, críticos y editores, a aceptar traducciones con un elevado grado de "choque" y "extrañamiento". Hoy día, las posibilidades quizás sean mejores que nunca para reconfigurar, aproximadamente, el insólito estilo roseano, juego ambiguo entre revelación, alusión y opacidad, sin desanimar al lector, ofreciéndole una cualidad que Paul Celan reivindica de toda traducción poética: "fremde Nähe" — “cercanía ajena"—.

Recebido em 08/09/2017

Aceito em 21/11/2017 